\title{
Flavonoids: New Frontier for Immuno-Regulation and Breast Cancer Control
}

\author{
Meenakshi Sudhakaran ${ }^{1,2}$, Sagar Sardesai ${ }^{3, *}$ and Andrea I. Doseff ${ }^{1,4, *}$ \\ 1 Department Physiology, Michigan State University, East Lansing, MI 48824, USA \\ 2 Physiology Graduate Program, Michigan State University, East Lansing, MI 48824, USA; sudhaka7@msu.edu \\ 3 Division of Hematology, Department of Internal Medicine, The Ohio State University, \\ Columbus, $\mathrm{OH} 43210$, USA \\ 4 Department Pharmacology and Toxicology, Michigan State University, East Lansing, MI 48824, USA \\ * Correspondence: Sagar.Sardeasai@osumc.edu (S.S.); doseffan@msu.edu (A.I.D.)
}

Received: 25 February 2019; Accepted: 5 April 2019; Published: 16 April 2019

\begin{abstract}
Breast cancer (BC) remains the second most common cause of cancer-related deaths in women in the US, despite advances in detection and treatment. In addition, breast cancer survivors often struggle with long-term treatment related comorbidities. Identifying novel therapies that are effective while minimizing toxicity is critical in curtailing this disease. Flavonoids, a subclass of plant polyphenols, are emerging as promising treatment options for the prevention and treatment of breast cancer. Recent evidence suggests that in addition to anti-oxidant properties, flavonoids can directly interact with proteins, making them ideal small molecules for the modulation of enzymes, transcription factors and cell surface receptors. Of particular interest is the ability of flavonoids to modulate the tumor associated macrophage function. However, clinical applications of flavonoids in cancer trials are limited. Epidemiological and smaller clinical studies have been largely hypothesis generating. Future research should aim at addressing known challenges with a broader use of preclinical models and investigating enhanced dose-delivery systems that can overcome limited bioavailability of dietary flavonoids. In this review, we discuss the structure-functional impact of flavonoids and their action on breast tumor cells and the tumor microenvironment, with an emphasis on their clinical role in the prevention and treatment of breast cancer.
\end{abstract}

Keywords: cancer therapeutics; cancer prevention; metastasis; chemoprevention; flavonoids; immune-regulation; apigenin; obesity; foods for health; inflammation; macrophages

\section{Introduction}

Breast cancer $(\mathrm{BC})$ is the most commonly diagnosed cancer in women worldwide and the second most common cause of cancer-related mortality in women in the US [1,2]. Despite the advancement on early detection methods and intensive interventions, questions pertaining to the mechanisms underlying the aggressiveness of certain forms of cancer such as the triple negative breast cancer (TNBC) remain unanswered. Identifying additional treatments and preventive approaches continues to be critical in curtailing BC. Epidemiological studies suggest that the consumption of healthy diets, rich in fruits and vegetables, and body weight are positively associated with a reduced incidence of BC [3,4]. Flavonoids, plant polyphenols broadly present in fruits and vegetables, are emerging as promising arsenals for the prevention and treatment of cancer and other chronic inflammatory diseases [5-9]. Flavonoids show anti-carcinogenic, anti-metastatic and immuno-modulatory activities in cellular and preclinical animal models making them potential candidates in cancer prevention and treatment. Despite the well-established role of flavonoids as antioxidants, recent evidences show that flavonoids directly interact with proteins, making them ideal small molecules for the modulation 
of enzymes, transcription factors and receptors [10]. These novel properties of flavonoids propose new platforms to modulate tumor signaling, overcome chemo-resistance and re-educate the tumor microenvironment (TME). Unraveling these novel mechanisms of action of flavonoids offers great clinical opportunities. In this review, we discuss the structure-functional impact of flavonoids and their action on tumor cells and TME, with an emphasis on their clinical role in the prevention and treatment of breast cancer.

\section{Breast Cancer}

Breast cancer is a leading cause of cancer-related mortality among women worldwide. Extensively complex and heterogeneous, BC features characteristic histological patterns and diverse biological phenotypes and clinical behaviors. Advancements in high throughput techniques have shed light into providing a better understanding of this heterogeneity, molecular features and in developing new predictive and prognostic factors to support therapy [11,12]. Hierarchical gene clustering analysis and gene-expression profiling of primary breast tumors led to its molecular classification comprising of four subtypes; luminal, human epidermal growth factor receptor (HER2) enriched, normal breast-like and basal like (Table 1) [13-15]. While luminal (A and B) BC is characterized by the presence of hormone receptors estrogen and progesterone positive (ER+ and/or PR+) biomarkers with good prognosis, HER2 enriched are hormone receptor negative and HER2 positive BC accompanied by a relatively worse prognosis. Although normal-like and luminal A cancer types share the same biomarker status, normal-like express normal breast profiling pattern and low proliferation marker Ki67 with a moderately worse prognosis. Basal-like, which also includes TNBC, has expression patterns either lacking or having a low expression of receptors (ER-, PR-, HER2-) and a high expression of basal markers like keratins with phenotype being more aggressive in nature.

Table 1. Breast cancer (BC) molecular subtypes.

\begin{tabular}{ccc}
\hline Subtype & Biomarker Status & Prognosis \\
\hline Luminal A & ER+ and/or PR+, HER2-, Ki67- & Good \\
\hline Luminal B & $\begin{array}{l}\text { ER+ and/or PR+, HER2-, Ki67+ } \\
\text { ER+ and/or PR+, HER2+, Ki67+ }\end{array}$ & Medium \\
\hline HER2 enriched & ER-, PR-, HER2+ & Poor \\
\hline Basal-like & $\begin{array}{c}\text { ER-, PR-, HER2-, basal markers } \\
\text { (keratin 5, 6, 14, 17, EGFR etc.) }\end{array}$ & Poor \\
\hline Normal-like & ER+ and/or PR+, HER2-, Ki67- & Medium \\
\hline
\end{tabular}

ER: Estrogen receptor; HER2: Human epidermal growth factor receptor; PR: Progesterone receptor; Ki67: Proliferation marker protein; EGFR: Epidermal growth factor receptor.

The non-metastatic disease is primarily treated with curative intent surgery with or without adjuvant radiation. The use of systemic therapy (adjuvant or neoadjuvant) is guided by tumor characteristics, patient factors and preferences. For instance, BC patients with hormone receptor positive or HER2-amplified tumors respond favorably to targeted therapies. Endocrine therapy complimentary to surgery has prolonged the disease-free survival and overall survival rate in patients with early as well as relapsed ER+ BC [16-18]. Despite being approved by the US-FDA (US Food and Drug Administration) as HER2 directed therapies and ameliorating the overall survival in combination with chemotherapy, many HER2+ BC patients have shown to acquire the inherent drug resistance. Advanced cancer and TNBC, which are associated with significantly worse prognosis, are more often encountered in younger women and approved chemotherapy regimens are lacking [19,20]. Currently, advanced $\mathrm{BC}$ is incurable and poses a significant treatment challenge with a median overall survival (OS) of five years or less especially in TNBC with no available targeted therapies [21-23].

The Omic platforms have increased our understanding of tumor biology, which has led to novel treatments targeting drug resistance, oncogenic pathways and TME [24,25]. Several ongoing 
randomized controlled trials are investigating new drug applications targeting actionable genomic mutations in advanced BC and of particular interest is the development of immune-oncology compounds in certain BC subtypes [26-31]. However, most novel treatments are not bereft of side effects. A growing number of $\mathrm{BC}$ survivors suffer from long-term treatment related comorbidities such as neuropathy, obesity, cognitive deficits and cardiovascular disease [32-37]. Additionally, rising health care costs and time for therapeutic drug development are significant limitations to improving patient care in oncology $[38,39]$. Identifying cost-effective treatments that can rapidly move from bench to bedside with minimal additional toxicity is critical.

\section{Flavonoids Classification and Distribution}

Flavonoids are secondary metabolites broadly distributed in plants. The basic structure of flavonoids comprises two benzene rings (A and B) linked through a heterocyclic pyrone ring (C) [40,41]. Based on the chemical arrangements of hydroxy groups, annularity of ring $C$, degree of oxidation and the connection position of ring B, flavonoids are categorized into different sub-groups that include: flavones, flavonols, flavanones, flavanonols, flavanols, isoflavones and anthocyanidins (Figure 1) [41-43].

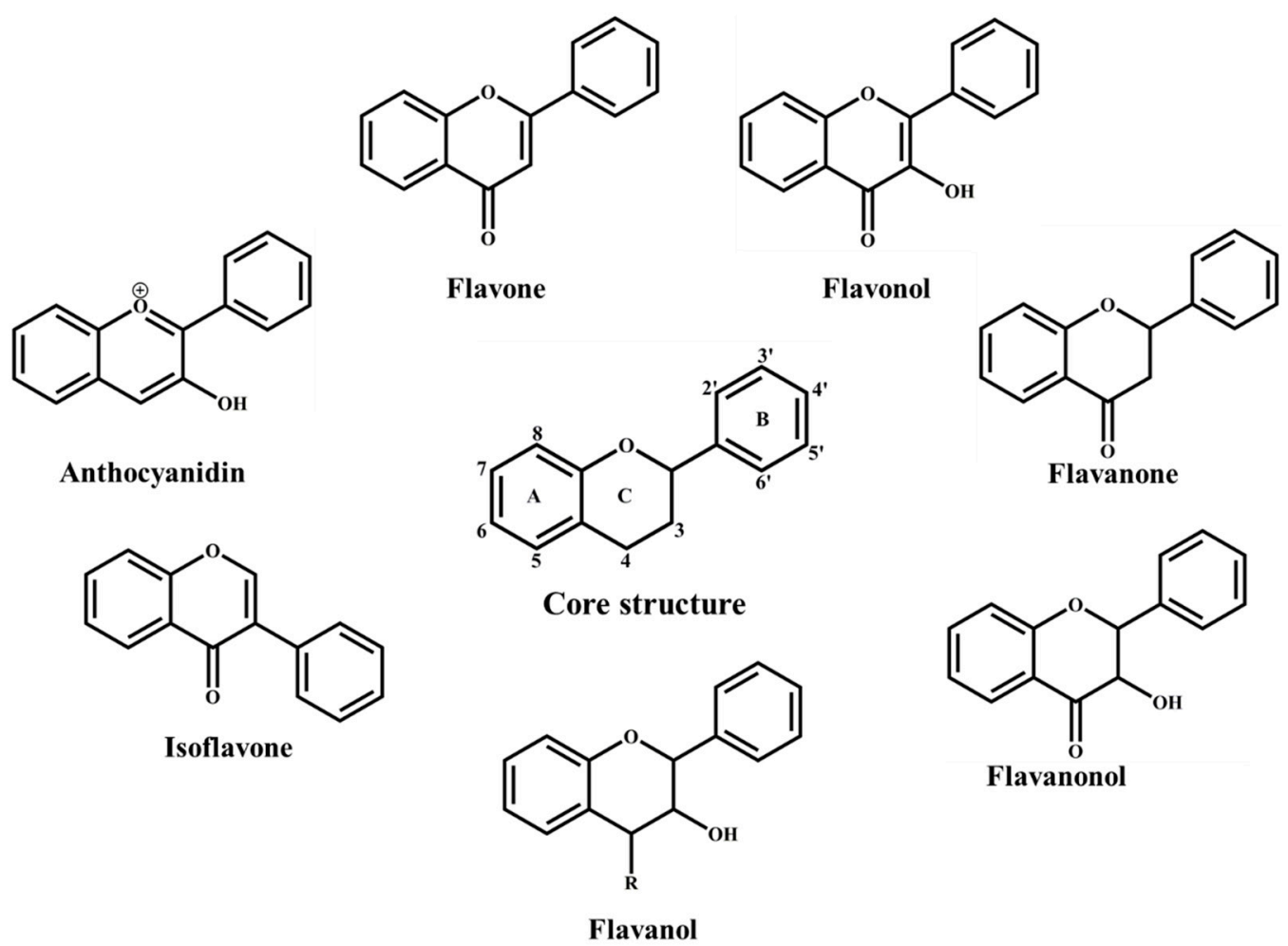

Figure 1. Flavonoid basic structure and classification.

Flavones represent one of the largest groups and possess a functional $\mathrm{C} 2=3$ double bond in the basic structure. Flavonoids are often found to be hydroxylated, glycosylated (bound to sugars) or methoxylated in different positions. This diversity in the degree of substitution, polymerization, conjugation and the substitution of functional groups accounts for the wide spectrum of biological and pharmacological activities and also determines their availability in vivo.

The bioavailability of flavonoids varies among different subclasses but has shown to be quite poor in several of them, thereby being a hindrance in reaching effective concentrations in vivo. Structural features play a crucial role in determining the absorption and bioavailability of flavonoids. For example, absorption of glycosides is generally lower than the aglycone counterparts, with the rate of deglycosylation being determined by the number and type of sugars [44,45]. We showed that the 
presence of sugars reduces the cellular absorption of flavones, limiting the immuno-modulatory activity of glycosides as compared to aglycones and thereby affecting their bioavailability in vivo [46]. The type of glycosylation affects the hydrolysis of flavonoids in the intestine. The hydrolysis of C-glycosyl flavonoids for example, is less effective as compared to O-glycosides. In contrast to the hydroxylated forms, O-methylated flavonoids possess better bioavailability owing to its delayed absorption and increased permeability across membranes [46-49]. There is a paucity of data on the relationship between the structure activity and biological fate of the flavonoids. Notwithstanding their broad distribution, the bioavailability of flavonoids is poor and demands the establishment of beneficial dietary recommendations. The emerging importance of the flavonoids in human diet and health calls for the need to further evaluate the relationship between the structure and function and their impact in cancer biology.

\section{Flavonoids: Molecular Mechanisms of Action}

\subsection{Antioxidant Effects of Flavonoids in Breast Cancer}

The health benefits of the flavonoids have been historically ascribed to their chelating and antioxidant properties led by their innate chemical structure [50]. The presence of multiple hydroxyl groups along with a highly conjugated delocalized electron system enhance the free radical scavenging nature of the flavonoids and its interference with the redox activity of the cell [51]. In general, flavonoids have been shown to block the production of reactive oxygen species (ROS) in macrophages, thereby mediating their immune modulating activity [52-55].

In vitro studies on hormone sensitive ER+ human BC T47D and MCF-7 cell lines have shown that flavonoids found in wine, like quercetin and resveratrol, inhibit proliferation by antagonizing hydrogen peroxide $\left(\mathrm{H}_{2} \mathrm{O}_{2}\right)$ [56]. Flavones possessing multiple hydroxyl groups, such as apigenin and luteolin, induced apoptosis and cell cycle arrest in MCF-7 and the TNBC cell lines through the inhibition of PI3K/Akt and increased FOXO3a (forkhead box protein) activation, which is associated with ROS reduction [57]. Butein, a tetrahydroxy chalcone, suppressed the growth of HCC70 (TNBC), BT-474 (HER2+) and T47D (ER+) human BC cell lines by reducing ROS and inducing apoptosis, as evidenced by the increased caspase-3 and caspase-9 activities [58]. Interestingly, flavonoids can also induce ROS accumulation, depending on the cell type and culture conditions, suggesting additional mechanisms responsible for triggering cell death. The flavanone naringenin induces ROS dependent apoptosis in human MDA-MB-468 TNBC cells [59]. Myricetin can suppress the growth of MDA-MB-231 and MDA-MB-468 cell lines by activating pro-apoptotic agents via a pro-oxidant effect, which is mediated by $\mathrm{H}_{2} \mathrm{O}_{2}$ generation [60-62]. The flavone 5,7-dihydroxy, 8-nitrochrysin, exerted cytotoxicity on HER2 overexpressing MDA-MB-453 human BC cells by the generation of ROS and Akt dephosphorylation [63,64]. Silibinin, a mixture of flavanolignans, induced apoptosis in MDA-MB-231 cells through ROS-dependent Notch-1/ERK/Akt pathway and nuclear translocation of the apoptosis-inducing factor (AIF) [65]. Flavonoids can also induce apoptosis in a ROS-independent pathway. Common shortcoming in the field is that sometimes the observed changes in activities represent secondary effects that might not be necessary and/or sufficient for the biological effects exerted by the flavonoids. Illustrating this point, our group showed that the flavone apigenin induces a quick ROS production followed by caspase-3-dependent apoptosis in leukemia cells. However, we found that ROS inhibitors failed to inhibit apoptosis, clearly indicating that ROS production was dispensable for the apigenin-induced cell death [66]. Therefore, the beneficial effects of flavonoids in cellular models of BC can be due to antioxidant-dependent and independent pathways. Hence, caution on the interpretation of the results and studies devoted to a deeper dissection of the mechanisms of action are much needed in the field of flavonoids for health.

In BC xenograft mouse models, flavonoids have shown to significantly reduce cell growth through the production and scavenging of ROS. The myricetin derived flavonoid oncamex, induced increased superoxide production and cytotoxicity in MDA-MB-231 xenografts [67]. Treatment of 
BT-474 xenografts with butein reduced tumor growth through the reduction of ROS and induction of apoptosis [58]. Flavonoids extracted from Radix Glycyrrhiza attenuated tumor mass of MDA-MB-231 xenografts by the inhibition of iNOS (inducible Nitric Oxide Synthase) and inactivation of the JAK2/STAT3 signaling pathway [68]. Apigenin and luteolin inhibited intravasation mechanisms in the MDA-MB-231 breast cancer spheroids thereby hindering its growth and migration through the lymph endothelial barrier [69]. This study reveals insights into the potential effects of flavonoids to inhibit metastasis. Future studies using 3D cultures of BC cell lines and with patient derived xenografts (PDX) will be crucial for evaluating the clinical potential of flavonoids alone or in combination with chemotherapeutic drugs in BC treatment.

$\mathrm{BC}$ recurrence, metastasis, and the limited success of current therapies are in part ascribed to the complexity of the TME. Macrophages, key immune cells abundant in the TME, regulate tumor growth, invasion, metastasis and harbor immune-suppressive conditions [70,71]. Increased numbers of tumor associated macrophages (TAMs) in the TME and circulatory myeloid progenitors, including inflammatory monocytes (i-Mo) and myeloid derived suppressor cells (MDSCs), are responsible for defective immune-surveillance [72-74]. The presence of these cells has been correlated with increased metastasis and poor clinical prognosis [75]. There is also compelling evidence that TAMs limit the efficacy of chemotherapy [76-79]. Thus, the ability of flavonoids to target the macrophage function has attracted great interest as a potential approach to increase the efficacy of current standard of care and reduce the immunosuppressive conditions of the TME in BC.

We showed that the flavone apigenin exerts immunoregulatory activity in macrophages and its myeloid progenitors. Apigenin reduces the phosphorylation of p65 subunit of nuclear factor $N F k B$, responsible for its transcriptional activity [52]. NFKB is a key transcription factor in cancer controlling both the proliferation of cancer cells and the immune response [80]. NFkB regulates the expression of tumor necrosis factor alpha $(\mathrm{TNF} \alpha)$ and interleukin-1 $\beta$ (IL-1 $\beta)$ in macrophages, whereas in tumor cells, increases the expression of anti-apoptotic molecules [81], contributing to increased resistance of cancer cell to current chemotherapies. A study involving multiple hydroflavones reported that chrysin suppressed the level of IL-1 $\beta$ m-RNA in LPS/IFN- $\gamma$ (lipopolysaccharide/interferon gamma) activated RAW 264.7 mouse macrophages, whereas the addition of $\mathrm{OH}$ groups in the $\mathrm{C}$ ring (galanin) and $\mathrm{B}$ ring (quercetin and kaempferol) decreased this effect [82]. We showed that apigenin reduces $\mathrm{TNF} \alpha$ and IL-1 $\beta$ expression in macrophages, even when added after inflammatory stimuli, suggesting its therapeutic potential [52]. Apigenin also reduces nitric oxide synthase (NOS) and cyclooxygenase (COX) expression in macrophages [83,84]. Furthermore, using transgenic NFkB-luciferase reporter mice, we showed that apigenin decreases NFKB activity in vivo [85]. Apigenin was also found to induce apoptosis in mouse macrophage ANA-1 cells through the increased ROS accumulation and high caspase-3 activity followed by activation of the mitogen-activated protein kinase (MAPK) pathway [86]. However, the concentrations used in cellular and animal models are frequently unreachable in vivo, potentially disguising the main mechanisms and clinical potential (Table 2). Apigenin and quercetin inhibited the expression of TNF $\alpha$ in peripheral blood mononuclear cells (PMBC) by halting the NFkB pathway $[87,88]$. Citrus flavonoid, hesperidin, reduced the ROS generation in human neutrophils and induced caspase-3-dependent apoptosis [89,90]. Flavonoids like epigallocatechin gallate (EGCG), found in green tea, can suppress human monocytic derived dendritic cells through apoptosis and the suppression of cell surface molecules and antigen presentation, suggesting its potential for immuno-therapies [91,92]. Luteolin inhibited lipopolysaccharide induced COX-2 expression and xanthine oxidase generated superoxide in the RAW 246.7 macrophages [93]. In a study pertaining to the effect of flavonoids on macrophage activation, it was shown that flavonols with $3^{\prime}$ and 4' hydroxylations in the B ring, as in quercetin and kaempferol, exerted the highest degree of TNF $\alpha$ inhibition. Whereas, flavones like apigenin, luteolin and diosmetin were more effective in suppressing the NO and IL- $1 \beta$ production when compared to the flavonols [94,95]. Overall, these findings suggest that flavonoids can affect tumors and its metastases by affecting other components of the TME ecosystem. 
Table 2. Flavonoid doses in different experimental models.

\begin{tabular}{|c|c|c|c|c|c|}
\hline Study Type & Experimental Model & Treatments & Dose & Results & Reference \\
\hline \multirow{19}{*}{ Cellular Studies } & T47D and MCF-7 & Wine polyphenols & $1 \mathrm{pM}-100 \mathrm{nM}$ & Inhibited growth and antagonize $\mathrm{H}_{2} \mathrm{O}_{2}$ & [56] \\
\hline & HCC70, BT-474 and T47D & Butein & $0.001-100 \mu \mathrm{g} / \mathrm{mL}$ & Induced apoptosis through ROS reduction & [58] \\
\hline & MDA-MB-468 & Naringenin & $2.5-50 \mu \mathrm{M}$ & Oxidative stress induced apoptosis & [59] \\
\hline & $\begin{array}{l}\text { MDA-MB-231 and } \\
\text { MDA-MB-468 }\end{array}$ & Myricetin & $20-100 \mu \mathrm{M}$ & Oxidative stress induced apoptosis & [60] \\
\hline & MDA-MB-453 & 5,7-dihydroxy, 8-nitrochrysin & $2-8 \mu \mathrm{M}$ & Induced apoptosis by generation of ROS & [63] \\
\hline & MDA-MB-231 & Silibinin & $30 \mu \mathrm{M}$ & Induced apoptosis & [64] \\
\hline & $\begin{array}{l}\text { Human monocytes and RAW } \\
264.7\end{array}$ & Apigenin & $0.1-25 \mu \mathrm{M}$ & $\begin{array}{l}\text { Reduced NFKB phosphorylation, TNF- } \alpha \text { and IL-1 } \beta \\
\text { expression }\end{array}$ & [52] \\
\hline & RAW 264.7 & Chrysin & $30 \mu \mathrm{M}$ & Suppression IL-1 $\beta$ expression & [82] \\
\hline & RAW 264.7 & Apigenin & $10-25 \mu \mathrm{M}$ & Reduced NOS and COX expression & [83] \\
\hline & ANA-1 & Apigenin & $12.5-200 \mu \mathrm{M}$ & Induced apoptosis & [84] \\
\hline & Human PBMC & Quercetin & $1-50 \mu \mathrm{M}$ & Inhibited TNF- $\alpha$ expression & [87] \\
\hline & Human Neutrophils & Hesperidin & $1-100 \mu \mathrm{M}$ & Reduced ROS generation and induced apoptosis & [90] \\
\hline & Human Dendritic cells & EGCG & $10-100 \mu \mathrm{M}$ & Induced apoptosis & [92] \\
\hline & RAW 264.7 & Luteolin & $25-100 \mu \mathrm{M}$ & Inhibited COX-2 and xanthine oxidase expression & [93] \\
\hline & $\begin{array}{l}\text { Bone marrow derived mouse } \\
\text { macrophages }\end{array}$ & Quercetin and Kaempferol & $25-50 \mu \mathrm{M}$ & Inhibited TNF- $\alpha$ expression & [95] \\
\hline & MCF-7 & Apigenin and Chrysin & $10-50 \mu \mathrm{M}$ & BCRP inhibitors & [96] \\
\hline & MCF-7 and T47D & $\begin{array}{l}\text { Methoxyflavones from } \\
\text { Tanacetum gracile }\end{array}$ & $1.5-5 \mu \mathrm{M}$ & Induced cell cycle arrest through tubulin binding & [97] \\
\hline & MDA-MB-231 & Apigenin & $25 \mu \mathrm{M}$ & $\begin{array}{l}\text { Inhibited hnRNPA2 dimerization affecting its splicing } \\
\text { activity }\end{array}$ & [98] \\
\hline & MCF-7 & Apigenin & $25-100 \mu \mathrm{M}$ & Suppressed MUC-1 expression and induced apoptosis & [99] \\
\hline
\end{tabular}


Table 2. Cont.

\begin{tabular}{|c|c|c|c|c|c|}
\hline Study Type & Experimental Model & Treatments & Dose & Results & Reference \\
\hline \multirow{13}{*}{ Cellular Study } & CD4 T cells & Apigenin & $12.5-75 \mu \mathrm{M}$ & $\begin{array}{l}\text { Potentiated activation induced cell death by } \\
\text { suppressing NFKB regulated anti-apoptotic pathways }\end{array}$ & [100] \\
\hline & Dendritic cells & Quercetin & $50 \mu \mathrm{M}$ & Attenuated LPS induced DC activation & [101] \\
\hline & MCF-7 & Apigenin & $20-80 \mu \mathrm{M}$ & $\begin{array}{l}\text { Reduced cell growth and expression of MDR1 and } \\
\text { P-gp in MCF-7-doxorubicin resistant cells }\end{array}$ & [102] \\
\hline & $\begin{array}{l}\text { MCF-7, MDA-MB-231 and } \\
\text { HMF }\end{array}$ & Rutin & $20 \mu \mathrm{M}$ & $\begin{array}{l}\text { Increased the cytotoxicity of cyclophosphamide and } \\
\text { methotrexate }\end{array}$ & [103] \\
\hline & MDA-MB-231 & EGCG & $10-25 \mu \mathrm{M}$ & $\begin{array}{l}\text { Synergistic enhancement of cytotoxicity with } \\
\text { tamoxifen }\end{array}$ & [104] \\
\hline & MCF-7 & Resveratrol & $50-250 \mu \mathrm{M}$ & Increased sensitivity to doxorubicin & [79] \\
\hline & MDA-MB-231 and MCF-7 & Resveratrol & $80-180 \mu \mathrm{M}$ & Synergistic inhibition of growth with doxorubicin & [105] \\
\hline & MCF-7 & Apigenin & $30 \mu \mathrm{M}$ & Enhanced cisplatin cytotoxic activity & [106] \\
\hline & BT-474 and SK-BR3 & Flavopiridol & $50-100 \mathrm{nM}$ & $\begin{array}{c}\text { Synergistic inhibition of cell proliferation with } \\
\text { trastuzumab }\end{array}$ & [107] \\
\hline & $\begin{array}{l}\text { MDA-MB-231, MDA-MB-468 } \\
\text { and SK-BR3 }\end{array}$ & Flavopiridol & $0.2 \mu \mathrm{M}$ & Enhanced sorafenib induced cytotoxicity & [108] \\
\hline & BT47D and MDA-MB-231 & Apigenin & $10-80 \mu \mathrm{M}$ & Induced apoptosis and autophagy & [109] \\
\hline & MDA-MB-231 & Wogonin & $50-100 \mu \mathrm{M}$ & Sensitized TRAIL-induced apoptosis & [110] \\
\hline & $\begin{array}{l}\text { RAW } 264.7 \text { macrophages and } \\
\text { 3T3-L1 adipocytes co-culture }\end{array}$ & Luteolin & $1-20 \mu \mathrm{M}$ & $\begin{array}{l}\text { Suppressed the adipocyte-dependent activation } \\
\text { ofmacrophage }\end{array}$ & [111] \\
\hline 3D Study & MDA-MB-231 & Apigenin and Luteolin & $20 \mu \mathrm{M}$ & $\begin{array}{c}\text { Attenuate growth and intravasation through } \\
\text { endothelial barrier }\end{array}$ & [69] \\
\hline
\end{tabular}


Table 2. Cont.

\begin{tabular}{|c|c|c|c|c|c|}
\hline Study Type & Experimental Model & Treatments & Dose & Results & Reference \\
\hline \multirow{11}{*}{ Animal Study } & $\begin{array}{c}\text { BALB/C-Tg } \\
\text { (NFkB-RE-luc)-Xen mice }\end{array}$ & Apigenin & $\begin{array}{l}50 \mathrm{mg} / \mathrm{kg} \text { body } \\
\text { weight }\end{array}$ & Reduced NFKB activity in lungs in vivo & [85] \\
\hline & $\begin{array}{l}\text { CD-1 immunodeficient mice } \\
\text { bearing MDA-MB-231 tumor }\end{array}$ & Oncamex & $\begin{array}{l}25 \mathrm{mg} / \mathrm{kg} \text { body } \\
\text { weight }\end{array}$ & Inhibited tumor growth & [67] \\
\hline & $\begin{array}{l}\text { Athymic nu/nu nude mice } \\
\text { bearing MDA-MB-231 tumors }\end{array}$ & Radix Glycyrrhiza extracts & $\begin{array}{l}20-100 \mathrm{mg} / \mathrm{kg} \text { body } \\
\text { weight }\end{array}$ & Attenuated tumor growth through iNOS inhibition & [68] \\
\hline & C57BL/6 mice & Luteolin & $\begin{array}{l}\text { HFD with } 0.01 \% \\
\quad \text { luteolin }\end{array}$ & $\begin{array}{l}\text { Inhibited inflammatory macrophage polarization in } \\
\text { adipose tissue }\end{array}$ & [112] \\
\hline & C57BL/6 mice & Quercetin & $\begin{array}{l}\text { HFD with } 0.1 \% \\
\text { luteolin }\end{array}$ & $\begin{array}{l}\text { Attenuated macrophage recruitment and modulated } \\
\text { M1/M2 macrophage ratio }\end{array}$ & [113] \\
\hline & $\begin{array}{l}\text { BALB/c mice bearing } 4 \mathrm{~T} 1 \\
\text { tumors }\end{array}$ & Quercetin & $5 \mathrm{mg} / \mathrm{kg}$ body weight & $\begin{array}{l}\text { Synergistic inhibition of tumor growth with } \\
\text { doxorubicin }\end{array}$ & [114] \\
\hline & $\begin{array}{l}\text { Athymic nu/nu nude mice } \\
\text { bearing BT47D tumors }\end{array}$ & Apigenin & $\begin{array}{l}50 \mathrm{mg} / \mathrm{kg} \text { body } \\
\text { weight }\end{array}$ & $\begin{array}{l}\text { Inhibited the progression progestin dependent BT- } 474 \\
\text { xenograft tumors in nude mice through apoptosis }\end{array}$ & [115] \\
\hline & $\begin{array}{l}\text { Athymic nu/nu nude mice } \\
\text { bearing MDA-MB-231 tumors }\end{array}$ & Apigenin & $\begin{array}{l}25-50 \mathrm{mg} / \mathrm{kg} \text { body } \\
\text { weight }\end{array}$ & Inhibited tumor proliferation and proteasome activity & [116] \\
\hline & $\begin{array}{l}\text { Ovariectomized C57BL/6 } \\
\text { mice injected with E0771 cells }\end{array}$ & Naringenin & $\begin{array}{l}\text { HFD with } 1-3 \% \\
\text { naringenin }\end{array}$ & $\begin{array}{l}\text { Reduced adipose tissue mass and ameliorated } \\
\text { adipose tissue inflammation }\end{array}$ & [117] \\
\hline & C57BL/6 mice & $\begin{array}{l}\text { Hippophae rhamnoides L. seeds } \\
\text { extracts }\end{array}$ & $\begin{array}{l}\text { 100-300 mg/kg body } \\
\text { weight }\end{array}$ & Significant anti-obesity and anti-inflammatory effect & [118] \\
\hline & $\begin{array}{l}\text { Ovariectomized female } \\
\text { C57BL/6 mice }\end{array}$ & Resveratrol & $\begin{array}{l}\text { 300-600 mg/kg body } \\
\text { weight }\end{array}$ & $\begin{array}{l}\text { Inhibited obesity-associated increases in claudin-low } \\
\text { mammary tumor growth and macrophage infiltration }\end{array}$ & [119] \\
\hline
\end{tabular}

BRCP: Breast cancer receptor protein; hnRNPA2: heterogeneous nuclear ribonuclear protein A2; MUC-1: Mucin-1; DC: Dendritic cells; MDR1: Multidrug resistance 1; P-gp: P-glycoprotein;

TRAIL: TNF-related apoptosis-inducing ligand; HFD: High fat diet. 


\subsection{Flavonoid-Protein Interactions as Regulators of Breast Cancer}

Recent studies provide evidences that flavonoids can also exert their functions by targeting proteins directly. Their structural resemblance to certain estrogens is responsible for the ability of isoflavones (e.g., genistein) and flavanone (e.g., naringenin) to bind to the nuclear estrogen receptors $\mathrm{ER} \alpha$ and ER $\beta$ [120]. Their increased affinity for ER relies on the 7-OH of $\mathrm{A}$ ring and $4^{\prime}-\mathrm{OH}$ of $\mathrm{B}$ ring. However, glycosylated flavonoids like naringenin-7-O-glucoside have weaker affinity for ER. Flavonoids have also been found to act as competitive inhibitors of drug transporters, including the breast cancer receptor protein (BCRP) and the ABC transporters P-glycoprotein (P-gp) and multidrug resistance-associated proteins (MRP1 and MRP2) [121-123]. Structural based studies of flavonoids on MCF-7 cell lines resistant to the antineoplastic antibiotic mitoxantrone found that apigenin and chrysin increased the accumulation of mitoxantrone in BRCP overexpressing the MCF-7 cells [96]. Similar studies have confirmed the high inhibitory activity of $O$ - and $C$-methoxylated flavonoids, such as retusin and ayanin, in MCF-7 BRCP overexpressing cells, underscoring the potential role of the methyl groups in targeting proteins [121,124]. The ability of flavonoids to induce the cell cycle arrest can be attributed to the interaction of its different functional groups with cyclin dependent kinases (CDKs). Molecular dynamic simulations to understand the binding behavior of flavonoids that inhibit CDK6/cyclin D complex showed that hydroxyl groups at $3^{\prime}$ and $4^{\prime}$ positions of B ring (e.g., luteolin) are favorable for the hydrogen bond formation with $\mathrm{CDK} 6 /$ cyclin $\mathrm{D}$, in contrast to the 3-OH on the $\mathrm{C}$ ring found in galangin and the 5-OH found in the A ring of chrysin [125]. Apigenin induced G2/M cell cycle arrest in MCF-7 and MDA-MB-468 cell lines by modulating CDK1/cyclin B1 complex accompanied by ERK/MAPK inhibition [126]. Biochemical and molecular docking studies suggested that some methoxyflavones from Tanacetum gracile induce cell cycle arrest in MCF-7 and T47D through the direct binding of tubulin $[97,127]$.

The novel approach PD-Seq (phage display coupled with second generation sequencing), that combines the phage display with next generation sequencing, identified 160 direct targets of apigenin from more than 15,000 proteins represented in a human breast cancer library [98]. Notably, in this study our group identified that the top candidate directly interacting with high affinity to apigenin is the heterogeneous ribonuclear protein A2 (hnRNPA2). HnRNPA2 is a RNA binding protein responsible for regulating RNA stability, splicing, microRNA maturation and the recently reported gene expression [98]. HnRNPA2 can participate in enhancing the tumor potential of cells by directly regulating genes involved in resistance to apoptosis, inflammation, and metastasis [128-131]. We demonstrated that apigenin inhibits hnRNPA2 dimerization affecting its splicing activity. Notably, MDA-MB-231 cells treated with apigenin show splicing isoforms found in non-tumor cells, suggesting the potential of apigenin to reeducate the aberrant tumor-proteome. It would be interesting to see whether the ability of apigenin to interact with hnRNPA2 increases chemosensitization by overcoming the increased anti-apoptotic protection of tumor cells. Intriguing, hnRNPA2 was found to regulate the splicing of the pyruvate kinase (PKM2/PKM1), suggesting the ability of apigenin to regulate central metabolic hubs responsible for the Warburg's effect [132-136]. Apigenin also directly binds to MUC1 (Mucin 1), a key oncogene participating in tumor growth and metastasis $[103,104]$. MUC1 is also known to regulate metabolic reprogramming in the MDA-MB-231 cells by altering glutamine dependency of the cells which can be ascribed to the changes in glutamine metabolism [137]. Recent studies also showed that luteolin binds to the transcription factor HNF4 $\alpha$ (Hepatocyte Nuclear Factor 4 alpha), repressing fat metabolism [138]. Therefore, understanding these novel mechanisms of action of flavonoids should provide important insights into their prevention and therapeutic potential in breast cancer.

\section{Dietary Flavonoids and Breast Cancer}

Epidemiological studies and systematic analysis suggest that diets rich in flavonoids are inversely associated with BC risk [7,139-143]. The ability of flavonoids to modulate not only cancer cells but also other components of the TME has attracted great interest in the field, providing unique opportunities for the prevention and treatment of BC $[5,144]$. The health beneficial effects of flavonoids in cancer have 
been mainly focusing on the cancer cells, seeking to understand the regulation of tumor related genes, signaling pathways, metastasis, and resistance to apoptosis [145-150]. However, the breakthrough that flavonoids can modulate the TME provides unforeseen opportunities to halt tumor development, progression and metastasis [151-154]. Adipocytes, major constituents of BC TME, and its cross talk with cancer cells have strong implications in BC progression, invasion $[155,156]$, induction of aberrant gene expression profiles [157] and therapeutic resistance [158]. Importantly, flavonoids can inhibit adipogenesis, reduce obesity and obesity-related cancer $[117,118,159,160]$. In addition, adipocytes and macrophages contribute to the tuning of TME making them potential participants of obesity linked cancer and also promising targets for flavonoids [161]. The modulation of T cells by apigenin [100] and dendritic cells (DC) by quercetin [101] can be crucial for overcoming the immunosuppressive condition and inflammation [162,163]. The ability of flavonoids like quercetin and luteolin to target macrophages either by reducing their recruitment into the TME or by reprogramming TAMs from a M2 (tumor promoting) to M1 (tumor suppressive) phenotype has great implications in anti-cancer therapy $[112,113,164,165]$. Thus, this ability of flavonoids to modulate not only the cancer cells but also other TME accomplices gives them unique opportunities for $\mathrm{BC}$ prevention and therapeutic.

\subsection{Potential Role of Flavonoids in Breast Cancer Therapeutics}

Flavonoids have become widely studied in cellular models as a therapeutic agent owing to its low systemic toxicity and broad range of ant-carcinogenic activities. Cancer cells are adaptively resistant to chemotherapeutic drugs, which eventually engender multidrug resistant cells leading to the aggressive tumor growth and metastasis. Sensitization to chemotherapeutic drugs using naturally occurring flavonoids has become an approach of interest aiming to enhance the efficacy of cytotoxic effects, delay the incidence of acquired chemoresistance and halt proliferative pathways [166,167]. Inhibition of transporters like Pgp or MRP by flavonoids like quercetin and luteolin has resulted in an increased bioavailability of cytotoxic drugs, with a potential impact in the quality of life of BC patients $[5,168]$. Several studies using cellular models have provided strong evidence that flavonoids increase the efficacy of current therapies. Apigenin reduced the expression of MDR1, MRPs and P-gp in MCF-7-doxorubicin resistant cell lines by attenuating STAT3 signaling pathway [102]. Rutin increased the cytotoxicity of cyclophosphamide and methotrexate on MDA-MB-231, MCF-7 and primary human mammary fibroblasts (HMF) in a time dependent manner, by suppressing the expression of P-gp and $\mathrm{BCRP}$, arresting the cells at G2/M and G0/G1 phases and promoting cell apoptosis [103]. Isoflavones also effectively inhibit BCRP [122]. Epigallocatechin gallate with tamoxifen has shown to synergistically enhance the cytotoxic effect against MDA-MB-231 cell lines [104]. Resveratrol chemosensitization to doxorubicin functioned by hindering NFKB andby impeding the expression of Hsp27, an inhibitor of caspase-3, in MCF-7 cell lines [169-171]. The resveratrol-doxorubicin combination also showed a 2.5 fold of dose advantage in inhibiting growth, NFKB activity and inducing apoptosis in MDA-MB-231 and MCF-7 cell lines [105]. Apigenin enhanced cisplatin cytotoxicity through a p53 mechanism in MCF-7 cells [106]. Flavopiridol, a semisynthetic flavone and trastuzumab synergistically inhibited the P13k/Akt pathway and induced cell cycle arrest in SK-BR3 (HER2+) and BT-474 (ER+) cell lines [107]. It was also found to enhance the cytotoxicity induced by sorafenib, a Raf inhibitor, in MDA-MB-231, MDA-MB-468 and SK-BR3 cell lines. Interestingly, this synergy also reduced the primary tumor growth rates and metastatic tumor load in the lungs of MDA-MB-231 mammary fat pad engraftment mouse models, compared to treatment with either drug alone [108]. However, the combinational treatment of flavopiridol with docetaxel and trastuzumab at clinical levels did not report any significant effect. While quercetin or doxorubicin alone failed to cure tumor-bearing mice, a combination regime induced significant depletion of 4T1 BC and led to a long-term, tumor-free survival in mice bearing established breast tumor along with persistent T-cell tumor-specific responses [114]. These findings suggest that the anti-carcinogenic activities of flavonoids might be more effective in combination with other chemotherapeutic agents than when used alone. 
Mechanistically some flavonoids have been shown to increase the expression of receptors of therapeutic drugs. Flavones like chrysin [172], luteolin [173] and apigenin [174] have increased the expression of TRAIL receptor DR5 and thereby contributing to TRAIL induced and chemotherapeutic induced cytotoxicity in multiple cancer cell lines by inhibiting the NFKB pathway and activation of caspase-3, -8, -9 and -10. Thus, flavonoid and TRAIL combination treatments can be a promising therapy against malignant breast tumors. As potent apoptosis inducers, flavonoids are known to possess cytotoxicity against cancer cells. Apigenin can induce apoptosis through caspase activation, PARP cleavage and pro- and anti-apoptotic markers Bax/Bcl-2 ratio [109]. In BT-474 and MDA-MB-231 xenograft mice models, apigenin attenuated growth through the induction of apoptosis and inhibition of proteasome activity and VEGF $[115,116]$. Interestingly, wogonin, chrysin and apigenin were shown to induce TRAIL mediated apoptosis in MDA-MB-231 by downregulating cellular FLICE-like inhibitory protein (c-FLIP) expression and enhancing the expression of TRAIL DR5 [110]. We have earlier reported that apigenin, through its direct interaction with hnRNPA2, can reduce the levels of splice isoform

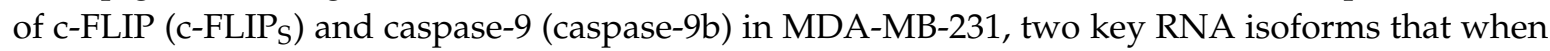
translated play a role in inhibiting apoptosis in cancer cells [98]. These findings together uphold the therapeutic effect of flavones such as apigenin in breast cancer cells, emphasizing the need for more studies in xenograft and preclinical models. Current research is also investigating the tuning of TME cells with the aid of flavonoids in order to enhance the effect of the chemotherapeutic drugs. Cellular studies show that genistein enhances the natural killer cell mediated cytotoxicity in MCF-7 cell lines $[175,176]$. Hence, there is an increasing need to identify chemosensitizers targeting preferentially to the tumor site that can provide low systemic toxicity and enhanced therapeutic drug efficacy. This clearly suggests the potential benefit of flavonoids as a chemosensitizer and an immunomodulator and hence emphasizes the need for combinational therapy as an approach to treat BC.

\subsection{Potential Role of Flavonoids in Breast Cancer Prevention}

Several epidemiological studies have shown that flavonoid rich diets are associated with the reduction of cancer risk in humans [177]. Mediterranean and Asian diets, which are highly rich in flavonoids, are often linked to a reduced risk of BC [178-180]. Increased consumption of isoflavones decreased the risk of estrogen-related cancers [181,182]. In a meta-analysis of 12 prospective cohort or case-control studies, the risk of BC was shown to be significantly decreased in women with a high intake of flavonols and flavones among post-menopausal women [141]. The Shanghai Women's Health Study showed higher levels of urinary epicatechins relating to a lesser incidence of breast cancer [183]. Similarly, several case control studies have reported that an increased intake of flavones can reduce the $\mathrm{BC}$ risk in women $[139,140,143]$.

Obesity is reaching epidemic levels across the world [184]. Approximately 35\% of the adult US population is overweight [185]. Obesity is often associated with a higher risk of developing BC and worse disease outcomes for women of all ages, irrespective of menopausal status [186]. In the Breast Cancer Prevention P-1 trial and World Health Initiative trial I, two among the many clinical trials conducted on obesity-BC relation, found that obesity was strongly associated with higher premenopausal [187] and postmenopausal BC risk [188], respectively. The Million Women Study, which included 45,037 breast cancer women between the ages of 50-64 years, identified a 30\% higher risk of developing postmenopausal breast cancer with obesity in UK women [189]. However, studies have shown that the risk for TNBC is higher among premenopausal women. The Cancer and Steroid Hormone, a population-based case-control study involving 3432 BC patients, reported a strong positive association between body mass index (BMI) and premenopausal TNBC risk [190]. Similarly, two meta-analyses of 1358 [191] and 620 [192] TNBC patients showed an $80 \%$ and $43 \%$ higher risk of developing TNBC in obese premenopausal women, respectively. Adipose tissues secrete cytokines and mediators which participate in creating an environment that favors cancer invasion and metastasis and are highly amplified in obese individuals [193]. Increased inflammatory condition, a characteristic of obesity, has also been largely associated to increased incidences and poor clinical outcomes [194-196]. 
Obese individuals display dysregulated genes expression, harboring TME inflammatory conditions that increase macrophage infiltration and adipokine imbalance in breast tissues [196-198]. Interestingly, a recent retrospective study showed a relation between obesity and the development of metastasis in $\mathrm{BC}$ patients and indicated that non-obese patients showed a better response to first-line metastatic chemotherapy treatment when compared to obese patients [199]. Investigations on flavonoids as potent agents against obesity and obesity-linked BC are gaining great interest. A study involving 9551 adults who participated in the National Health and Nutrition Examination Survey 2005-2008 reported that flavonoid consumption was inversely related to obesity in multivariate models of both men and women with significant reduction in BMI and C-reactive protein, a marker for inflammation, in US adults. Flavonoids from wheat (Triticum aestivum) sprout showed an inhibitory effect on adipogenesis through the downregulation of genes associated with lipid metabolism and adipogenic transcription factors [200]. Adipocytes are known to be potent modulators and recruiters of TAMs, thereby actively contributing to tumor growth. Luteolin strongly inhibited the interaction between 3T3-L1 adipocytes and RAW246 macrophages, thereby suppressing the production of pro-inflammatory mediators like TNF- $\alpha$ [111]. In animal models, flavonoid-enriched extract from Hippophaerhamnoides L. seed induced anti-obesity activities in high fat diet (HFD) C57BL/6 mice and recruited macrophage infiltration into the adipose tissues [118]. Naringenin not only reduced adipose mass and inflammation but had a moderate effect on the inhibition of tumor growth in C57BL/6 mice injected with E0771 mammary carcinoma cell line [127]. Resveratrol was reported to inhibit obesity-associated inflammation and claudin-low BC growth in diet induced obese C57BL/6 mice by inhibiting adipocyte hypertrophy and associated adipose tissue dysregulation [119]. Interestingly, two recent independent studies provided preclinical evidence using MMTV-PyMT murine models of BC that mammary adipose tissue inflammation induced by diet enhanced the recruitment of macrophages, increased tumor vascular density [201] and hormone production in pre- and postmenopausal hormone receptor positive BRCA [202], suggesting a role for obesity in creating a microenvironment favorable for the progression of breast cancer. However, there is a scarcity of data on the effect of flavonoids on HFD induced mammary tumorigenesis in preclinical PyMT mouse models, which can be highly corroborative for clinical studies targeting cancer prevention.

\section{Clinical Applications of Flavonoids: Challenges and Opportunities}

The increasing need to find more effective preventive and therapeutic approaches to treat and control BC has led to deepened studies on the role of flavonoids. This is particularly important in TNBC where poor survival rates and lack of effective therapies have prompted alternative preventive and therapeutic strategies. The scarce case control and cohort studies conducted so far indicate that a flavonoid rich diet can efficiently modify BC (Table 3). In a study involving 820 women from Greece, the regular intake of vegetables rich in flavones showed the correlation to a reduced risk of BC [143]. Patient and population-based studies on the potential relation of a flavonoid rich diet and risk of $\mathrm{BC}$ in women from Italy and Long Island showed a significantly inversed association, especially in postmenopausal women $[139,140]$. Interestingly, the high consumption of tea reduced the risk of ER negative BC in women who participated in the Cancer Prevention Study-II Nutrition Cohort owing to its rich flavan-3-ol content [203]. These findings have helped to establish a promising platform for treatment of $\mathrm{BC}$ with a high flavonoid diet. Soy protein food supplements rich in isoflavones have been of increased interest in treating women at high risk for or with BC. A meta-analysis of 35 studies including pre- and post-menopausal women reported that soy isoflavone intake can significantly lower BC risk in Asian women [180]. Soy intake after diagnosis of BC (including ER+, PR+, both and TNBC) was significantly associated with a reduced risk of recurrence in a large study of $\sim 9500$ women from US and China [204]. In a similar small-scale study with 358 incident BC patients from Korea, an estimated intake of $15 \mathrm{mg} /$ day isoflavones and $77 \mathrm{~g} /$ day soy showed an inverse association among postmenopausal women albeit no difference with respect to the ER+/PR+ status [205]. Findings in the previous section have confirmed that obesity increases the risk of $\mathrm{BC}$ development and relapse. A recent 
pilot study to test the feasibility of a 12-week soy-based meal replacement weight loss intervention among ER/PR negative $\mathrm{BC}$ survivors showed that an isoflavone rich diet reduced the body weight, total cholesterol and may impact the risk of BC recurrence [206]. However, a six-month intervention of soy isoflavones supplements in high risk adult western women showed no reduction in breast epithelial proliferation and, instead, had adverse effects in premenopausal women [207]. This could suggest that the use of dietary rich flavonoids seem warranted for BC control. Table 4 lists some of the completed clinical trials conducted on BC patients with flavonoids. Although several clinical trials involving flavonoids like genistein, soy isoflavones and flavopiridol have been successful in establishing favorable dose ranges without any adverse effects in patients, there is no promising data supporting the inhibitory effect of diet rich in these compounds on BC [208-210]. The absence of any profound effect from the combinational treatment with flavonoids and chemotherapeutic drugs points out that it demands more than just the mere establishment of effective dose range [208,211,212].

Table 3. Epidemiological prospective cohort and case control studies on dietary intake of flavonoids and breast cancer risk.

\begin{tabular}{|c|c|c|c|c|c|}
\hline $\begin{array}{l}\text { Subclass of } \\
\text { Flavonoid }\end{array}$ & Study Type & Region & Cases/Controls & $\begin{array}{c}\text { Association } \\
\text { with BC Risk }\end{array}$ & Reference \\
\hline Flavones & Hospital based & Greece & $820 / 1548$ & Inverse & [143] \\
\hline $\begin{array}{c}\text { Flavonols, } \\
\text { Flavones }\end{array}$ & Hospital based & Italy & $2569 / 2588$ & Inverse & [139] \\
\hline Flavones & Population-based & New York & $1434 / 1440$ & Inverse & [140] \\
\hline Flavonoids & Cohort & America & $1351 / 38,408$ & No effect & [213] \\
\hline Isoflavones & Cohort & Singapore and China & $629 / 35,303$ & Inverse & [214] \\
\hline Isoflavones & Cohort & Japan & $134 / 15,264$ & Inverse & [215] \\
\hline $\begin{array}{c}\text { Flavonols, } \\
\text { Flavones }\end{array}$ & Hospital based & Mexico & $141 / 141$ & Inverse & [216] \\
\hline Isoflavones & Population-based & Canada & $3024 / 3420$ & Inverse & [217] \\
\hline Isoflavones & Hospital-based & Korea & $358 / 360$ & Inverse & [205] \\
\hline Flavonoids & Cohort & Europe & $11,576 / 334,850$ & No effect & [218] \\
\hline $\begin{array}{c}\text { Flavone, } \\
\text { Flavan-3-ol }\end{array}$ & Cohort & America & 56,630 & Inverse & [203] \\
\hline Isoflavones & Population-based & England & $240 / 477$ & Inverse & [219] \\
\hline Isoflavones & Hospital-based & Japan, Brazil & $390 / 390$ & Inverse & [220] \\
\hline Isoflavones & Hospital-based & China & $438 / 438$ & Inverse & [221] \\
\hline Flavonoids & Cohort & Dutch & $199 / 3209$ & Inverse & [222] \\
\hline Isoflavones & Cohort & Multiethnic & $4769 / 84,450$ & No effect & [223] \\
\hline
\end{tabular}

Table 4. Clinical trials on dietary intake of flavonoids and breast cancer risk.

\begin{tabular}{cccccc}
\hline $\begin{array}{c}\text { Flavonoid } \\
\text { Subclass/Name }\end{array}$ & Study Type & Detail & Enrollment & Comments & $\begin{array}{r}\text { ClinicalTrials. } \\
\text { gov Identifier }\end{array}$ \\
\hline $\begin{array}{c}\text { Genistein (with } \\
\text { Gemcitabine) }\end{array}$ & Phase II & Stage IV BC & 17 & No effect & $\begin{array}{r}\text { NCT00244933 } \\
{[211]}\end{array}$ \\
\hline Genistein & Phase II & NA & 126 & No effect & $\begin{array}{r}\text { NCT00290758 } \\
{[207]}\end{array}$ \\
\hline Genistein & Phase I & NA & 30 & Dose rangestudy & $\begin{array}{r}\text { NCT00099008 } \\
{[210]}\end{array}$ \\
\hline Catechin & Phase I & HER2-, stage I-III BC & 40 & Dose range study & $\begin{array}{r}\text { NCT00516243 } \\
{[224]}\end{array}$ \\
\hline
\end{tabular}


Table 4. Cont.

\begin{tabular}{cccccc}
\hline $\begin{array}{c}\text { Flavonoid } \\
\text { Subclass/Name }\end{array}$ & Study Type & Detail & Enrollment & Comments & $\begin{array}{c}\text { ClinicalTrials. } \\
\text { gov Identifier }\end{array}$ \\
\hline Catechin & Phase II & NA & 1075 & No significant effect & $\begin{array}{r}\text { NCT00917735 } \\
{[225]}\end{array}$ \\
\hline $\begin{array}{c}\text { P276-00, flavone } \\
\text { derived }\end{array}$ & Phase I & TNBC & 11 & NA & $\begin{array}{c}\text { NCT01333137 } \\
{[226]}\end{array}$ \\
\hline Soy Isoflavone & Phase II & Post-menopausal & NA & NA & $\begin{array}{r}\text { NCT00200824 } \\
{[227]}\end{array}$ \\
\hline Soy Isoflavone & Phase III & Pre-menopausal & 100 & No adverse effect & $\begin{array}{r}\text { NCT00513916 } \\
{[209]}\end{array}$ \\
\hline Soy Isoflavone & NA & BRCA1 \& 2 stage I-III BC & 110 & No effect & $\begin{array}{c}\text { NCT01219075 } \\
{[228]}\end{array}$ \\
\hline $\begin{array}{c}\text { Flavopiridol (with } \\
\text { Trastuzumab) }\end{array}$ & Phase I & HER2+, stage IV BC & 50 & Dose range study & $\begin{array}{c}\text { NCT00039455 } \\
{[208]}\end{array}$ \\
\hline
\end{tabular}

Despite the numerous studies towards the development of new prevention and therapeutic strategies and preclinical trials, there is an increasing need for more warranted long term and population-based studies. Studies involving large cohorts covering a wide range of criteria must be considered for clinical trials. The benefits of flavonoids for chemoprevention in clinical trials have come across only restricted success, mainly owing to its varying bioavailability and ineffective systemic delivery, and thereby hindering in reaching effective concentrations. As reported in Table 2, flavonoids mostly exert cytotoxic effects only at moderately high doses, within a micromolecular concentration range [229]. Numerous in vitro studies demonstrating a constructive effect use doses that are several magnitudes higher than what the cells can essentially tolerate in vivo. This has posed a critical concern in establishing the effect of flavonoids in clinical trials. However, this can be overcome by using physiologically and clinically relevant concentrations and regimens of flavonoids in the in vitro and preclinical studies. Future studies addressing the bioavailability and efficacy of in vivo concentrations are of paramount significance to advance our understanding of how flavonoids exert their health beneficial effects.

The level of dietary flavonoids in the plasma differs in accordance with structural disparities, concentration and source. Nevertheless, attaining levels in plasma that would be sufficient to activate the anti-cancer effects through oral administration is indeed challenging. It is highly likely that these phytochemicals accumulate in the intestine and colon during systemic metabolism at higher levels than in plasma and thereby affecting its bioavailability. Apart from the structural characteristics of flavonoids, gut microbiota also plays a significant role in the metabolism of flavonoids [230]. The gut microbiota not only modifies the structure of the parent aglycones, conjugates and glycosides but also catabolizes chemical changes such as dihydroxylation, decarboxylation and hydrogenation of the compounds to generate smaller phenolic acids, which are highly bioavailable [231]. Some of these metabolites have higher retention levels in plasma compared to their parent compounds. For example, the plasma level of cyanidin glucosides is $0.02 \%$ while that of its microbiota dependent metabolite 3-4-dihydroxybenzoic acid is 44\% [232]. Much attention needs to be paid to the activities and availability of these metabolites. The absorption level of such metabolites degraded in the large intestine seems to be higher than that of the parent compound thereby being more effective [233]. Hence, bioavailability, microbiome and its governing factors must be taken into consideration in order to provide vital insights into food and clinical conclusions. Also, the anti-carcinogenic activity of the flavonoids would be contingent not only upon the flavonoid itself, but also on its metabolites, which makes the identification and quantification of these conjugates crucial in understanding the health benefits of dietary flavonoids in cancer patients. In addition, in accordance to the findings mentioned in the previous sections, the effect of flavonoid rich meal regimens on immune regulation must be considered for clinical trials, which can eventually be eye openers to new treatments. 
Furthermore, flavonoid metabolism can also be influenced by substantial inter-individual variations between the participants in the study, thereby demanding nutrigenomic approaches to ameliorate therapy [234]. It could be possible that the genomic variation in individuals can contribute to different retention levels and metabolism of flavonoids. The discrepancies pertaining to the effect of flavonoids observed in clinical trials could be explained with the help of individual variability with regards to intestine microbiota composition and gene polymorphisms [235]. Consequently, understanding nutrigenomics can help in establishing the individual nutritional requirements based on genetic makeup of the person as well as the relationship between diet and cancer. Dietary supplements as an alternative source of flavonoids have become prevalent in the last decade. However, there is insufficient data on the assessment if anticancer characteristics of flavonoid rich diet can be replaced with purified compounds such as flavonoid supplements. The food sources of flavonoids may include mixtures of secondary metabolites from plants which may not be true for the single compound dietary supplements [236]. Moreover, drug to nutrient and drug-to-drug interactions along with toxicity issues need to be considered for supplements. Therefore, there is a partial recognition of essentials and requirements for intervention studies which is a barrier to achieving the goal of evaluating the health benefits in clinical trials and developing dietary recommendations for flavonoid intake to prevent and treat cancer.

\section{Conclusions}

The value of flavonoids in health is well accepted, yet their role in BC prevention and treatment remains unclear. Conflicting reports and the limited number of clinical studies may have a great impact in the future utilization of this untapped natural compound in the clinical set up. Increasing our understanding of flavonoid structure, metabolism and molecular activities is paramount for the implementations of more effective clinical studies. Much has been learnt using cellular systems and pure flavonoids. As we move into the future, the field needs more investigations; broadened use of preclinical models, test effects of nutritional achievable doses and delivery systems compatible for human studies. The implementation of these strategies would accelerate the transition of using flavonoids in the clinic for the prevention and treatment of breast cancer.

Funding: Work in A.I. Doseff's lab is supported by grant USDA-AFRI-2018-03994, NSF-IOS-1733633 and MSU general funds. We are also grateful to the Ohio State University Comprehensive Cancer Center -Anna Wolfe fund 46040-313671 to S. Sardesai and A.I. Doseff that facilitates the current NCI clinical trial (NCT03139227).

Acknowledgments: We apologize to those of our colleagues who made important contributions, but which were omitted due to space limitations. We are especially grateful to all the cancer survivors that have donated their time and financially contributed to advance our knowledge of the basic mechanisms to stop cancer.

Conflicts of Interest: The authors declare no conflict of interest.

\section{References}

1. Breast Cancer: Prevention and Control. Available online: www.who.int/cancer/detection/breastcancer/en/ index1.htm (accessed on 5 February 2019).

2. Siegel, R.L.; Miller, K.D.; Jemal, A. Cancer statistics, 2018. CA Cancer J. Clin. 2018, 68, 7-30. [CrossRef]

3. Ferrini, K.; Ghelfi, F.; Mannucci, R.; Titta, L. Lifestyle, nutrition and breast cancer: Facts and presumptions for consideration. Ecancermedicalscience 2015, 9, 557. [CrossRef]

4. Nattenmuller, C.J.; Kriegsmann, M.; Sookthai, D.; Fortner, R.T.; Steffen, A.; Walter, B.; Johnson, T.; Kneisel, J.; Katzke, V.; Bergmann, M.; et al. Obesity as risk factor for subtypes of breast cancer: Results from a prospective cohort study. BMC Cancer 2018, 18, 616. [CrossRef]

5. Batra, P.; Sharma, A.K. Anti-cancer potential of flavonoids: Recent trends and future perspectives. 3 Biotech 2013, 3, 439-459. [CrossRef] [PubMed]

6. Vernarelli, J.A.; Lambert, J.D. Flavonoid intake is inversely associated with obesity and C-reactive protein, a marker for inflammation, in US adults. Nutr. Diabetes 2017, 7, e276. [CrossRef] [PubMed] 
7. Sak, K. Intake of individual flavonoids and risk of carcinogenesis: Overview of epidemiological evidence. Nutr. Cancer 2017, 69, 1119-1150. [CrossRef] [PubMed]

8. Parihar, A.; Doseff, A. Emerging roles of flavonoids in brain health. In Phytopharmaceuticals for Brain Health; CRC Press: Florida, FL, USA, 2017; pp. 175-196.

9. Beatrice Magne Nde, C.; Zingue, S.; Winter, E.; Beatriz Creczynski-Pasa, T.; Michel, T.; Fernandez, X.; Njamen, D.; Clyne, C. Flavonoids, breast cancer chemopreventive and/or chemotherapeutic agents. Curr. Med. Chem. 2015, 22, 3434-3446.

10. Hou, D.-X.; Kumamoto, T. Flavonoids as Protein Kinase Inhibitors for Cancer Chemoprevention: Direct Binding and Molecular Modeling. Antioxid. Redox Signal. 2010, 13, 691-719. [CrossRef]

11. Van't Veer, L.J.; Dai, H.; Van De Vijver, M.J.; He, Y.D.; Hart, A.A.; Mao, M.; Peterse, H.L.; Van Der Kooy, K.; Marton, M.J.; Witteveen, A.T. Gene expression profiling predicts clinical outcome of breast cancer. Nature 2002, 415, 530. [CrossRef]

12. Wirapati, P.; Sotiriou, C.; Kunkel, S.; Farmer, P.; Pradervand, S.; Haibe-Kains, B.; Desmedt, C.; Ignatiadis, M.; Sengstag, T.; Schütz, F. Meta-analysis of gene expression profiles in breast cancer: Toward a unified understanding of breast cancer subtyping and prognosis signatures. Breast Cancer Res. 2008, 10, R65. [CrossRef]

13. Perou, C.M.; Sørlie, T.; Eisen, M.B.; Van De Rijn, M.; Jeffrey, S.S.; Rees, C.A.; Pollack, J.R.; Ross, D.T.; Johnsen, H.; Akslen, L.A. Molecular portraits of human breast tumours. Nature 2000, 406, 747. [CrossRef]

14. Dai, X.; Li, T.; Bai, Z.; Yang, Y.; Liu, X.; Zhan, J.; Shi, B. Breast cancer intrinsic subtype classification, clinical use and future trends. Am. J. Cancer Res. 2015, 5, 2929-2943.

15. Molecular Subtypes of Breast Cancer. Available online: https://www.breastcancer.org/symptoms/types/ molecular-subtypes (accessed on 7 February 2019).

16. Baselga, J.; Perez, E.A.; Pienkowski, T.; Bell, R. Adjuvant trastuzumab: A milestone in the treatment of HER-2-positive early breast cancer. Oncologist 2006, 11, 4-12. [CrossRef]

17. Lumachi, F.; Santeufemia, D.A.; Basso, S.M. Current medical treatment of estrogen receptor-positive breast cancer. World J. Biol. Chem. 2015, 6, 231. [CrossRef]

18. Shah, R.; O'Regan, R.M. Adjuvant endocrine therapy. Cancer Treat. Res. 2018, 173, 15-29. [CrossRef]

19. Lin, N.U.; Vanderplas, A.; Hughes, M.E.; Theriault, R.L.; Edge, S.B.; Wong, Y.N.; Blayney, D.W.; Niland, J.C.; Winer, E.P.; Weeks, J.C. Clinicopathologic features, patterns of recurrence, and survival among women with triple-negative breast cancer in the National Comprehensive Cancer Network. Cancer 2012, 118, 5463-5472. [CrossRef]

20. Dent, R.; Trudeau, M.; Pritchard, K.I.; Hanna, W.M.; Kahn, H.K.; Sawka, C.A.; Lickley, L.A.; Rawlinson, E.; Sun, P.; Narod, S.A. Triple-negative breast cancer: Clinical features and patterns of recurrence. Clin. Cancer Res. 2007, 13, 4429-4434. [CrossRef] [PubMed]

21. Chia, S.K.; Speers, C.H.; D’Yachkova, Y.; Kang, A.; Malfair-Taylor, S.; Barnett, J.; Coldman, A.; Gelmon, K.A.; O'Reilly S, E.; Olivotto, I.A. The impact of new chemotherapeutic and hormone agents on survival in a population-based cohort of women with metastatic breast cancer. Cancer 2007, 110, 973-979. [CrossRef]

22. Greenberg, P.A.; Hortobagyi, G.N.; Smith, T.L.; Ziegler, L.D.; Frye, D.K.; Buzdar, A.U. Long-term follow-up of patients with complete remission following combination chemotherapy for metastatic breast cancer. J. Clin. Oncol. 1996, 14, 2197-2205. [CrossRef]

23. Dafni, U.; Grimani, I.; Xyrafas, A.; Eleftheraki, A.G.; Fountzilas, G. Fifteen-year trends in metastatic breast cancer survival in Greece. Breast Cancer Res. Treat. 2010, 119, 621-631. [CrossRef]

24. Cancer Genome Atlas, N. Comprehensive molecular portraits of human breast tumours. Nature 2012, 490, 61-70. [CrossRef]

25. Sorlie, T.; Perou, C.M.; Tibshirani, R.; Aas, T.; Geisler, S.; Johnsen, H.; Hastie, T.; Eisen, M.B.; van de Rijn, M.; Jeffrey, S.S.; et al. Gene expression patterns of breast carcinomas distinguish tumor subclasses with clinical implications. Proc. Natl. Acad. Sci. USA 2001, 98, 10869-10874. [CrossRef]

26. Nanda, R.; Chow, L.; Dees, E.C.; Berger, R.; Gupta, S.; Geva, R.; Pusztai, L.; Pathiraja, K.; Aktan, G.; Cheng, J.D. Pembrolizumab in patients with advanced triple-negative breast cancer: Phase Ib KEYNOTE-012 study. J. Clin. Oncol. 2016, 34, 2460-2467. [CrossRef]

27. Miles, D.; Roché, H.; Martin, M.; Perren, T.J.; Cameron, D.A.; Glaspy, J.; Dodwell, D.; Parker, J.; Mayordomo, J.; Tres, A. Phase III multicenter clinical trial of the sialyl-TN (STn)-keyhole limpet hemocyanin (KLH) vaccine for metastatic breast cancer. Oncologist 2011, 16, 1092-1100. [CrossRef] 
28. Mittendorf, E.; Clifton, G.; Holmes, J.; Schneble, E.; van Echo, D.; Ponniah, S.; Peoples, G. Final report of the phase I/II clinical trial of the E75 (nelipepimut-S) vaccine with booster inoculations to prevent disease recurrence in high-risk breast cancer patients. Ann. Oncol. 2014, 25, 1735-1742. [CrossRef] [PubMed]

29. Rugo, H.; DeLord, J.; Im, S. Preliminary efficacy and safety of pembrolizumab (MK-3475) in patients with PD-L1-positive, ER-positive (ER+)/HER-2 negative breast cancer enrolled in Keynote 028. In Proceedings of the San Antonio Breast Cancer Symposium, San Antonio, TX, USA, 8 December 2015.

30. Schmid, P.; Adams, S.; Rugo, H.S.; Schneeweiss, A.; Barrios, C.H.; Iwata, H.; Diéras, V.; Hegg, R.; Im, S.-A.; Shaw Wright, G. Atezolizumab and nab-paclitaxel in advanced triple-negative breast cancer. N. Engl. J. Med. 2018, 379, 2108-2121. [CrossRef] [PubMed]

31. Vonderheide, R.H.; LoRusso, P.; Khalil, M.; Gartner, E.M.; Khaira, D.; Soulieres, D.; Dorazio, P.; Trosko, J.; Ruter, J.; Mariani, G.L. Tremelimumab in combination with exemestane in patients with advanced breast cancer and treatment-associated modulation of ICOS expression on patient T cells. Clin. Cancer Res. 2010, 16, 3485-3494. [CrossRef]

32. Siegel, R.; DeSantis, C.; Virgo, K.; Stein, K.; Mariotto, A.; Smith, T.; Cooper, D.; Gansler, T.; Lerro, C.; Fedewa, S. Cancer treatment and survivorship statistics, 2012. CA Cancer J. Clin. 2012, 62, 220-241. [CrossRef] [PubMed]

33. Agrawal, S. Late effects of cancer treatment in breast cancer survivors. South Asian J. Cancer 2014, 3, 112-115. [CrossRef] [PubMed]

34. Chen, X.; Lu, W.; Zheng, W.; Gu, K.; Chen, Z.; Zheng, Y.; Shu, X.O. Obesity and weight change in relation to breast cancer survival. Breast Cancer Res. Treat. 2010, 122, 823-833. [CrossRef] [PubMed]

35. Majed, B.; Moreau, T.; Senouci, K.; Salmon, R.J.; Fourquet, A.; Asselain, B. Is obesity an independent prognosis factor in woman breast cancer? Breast Cancer Res. Treat. 2008, 111, 329-342. [CrossRef]

36. Saquib, N.; Flatt, S.W.; Natarajan, L.; Thomson, C.A.; Bardwell, W.A.; Caan, B.; Rock, C.L.; Pierce, J.P. Weight gain and recovery of pre-cancer weight after breast cancer treatments: Evidence from the women's healthy eating and living (WHEL) study. Breast Cancer Res. Treat. 2007, 105, 177-186. [CrossRef]

37. Shahrokni, A.; Wu, A.J.; Carter, J.; Lichtman, S.M. Long-term toxicity of cancer treatment in older patients. Clin. Geriatr. Med. 2016, 32, 63-80. [CrossRef]

38. Hernandez, J.J.; Pryszlak, M.; Smith, L.; Yanchus, C.; Kurji, N.; Shahani, V.M.; Molinski, S.V. Giving drugs a second chance: Overcoming regulatory and financial hurdles in repurposing approved drugs as cancer therapeutics. Front. Oncol. 2017, 7, 273. [CrossRef]

39. Schnipper, L.E.; Meropol, N. ASCO addresses the rising cost of cancer care. J. Oncol. Pract. 2009, 5, $214-215$. [CrossRef]

40. Jiang, N.; Doseff, A.I.; Grotewold, E. Flavones: From biosynthesis to health benefits. Plants 2016, 5, 27. [CrossRef]

41. Wang, T.-Y.; Li, Q.; Bi, K.-S. Bioactive flavonoids in medicinal plants: Structure, activity and biological fate. Asian J. Pharm. Sci. 2018, 13, 12-23. [CrossRef]

42. Panche, A.N.; Diwan, A.D.; Chandra, S.R. Flavonoids: An overview. J. Nutr. Sci. 2016, 5, e47. [CrossRef]

43. Quattrocchio, F.; Baudry, A.; Lepiniec, L.; Grotewold, E. The Science of Flavonoids; Springer: New York, NY, USA, 2006; pp. 97-122.

44. Hollman, P.C.H.; Bijsman, M.N.C.P.; van Gameren, Y.; Cnossen, E.P.J.; de Vries, J.H.M.; Katan, M.B. The sugar moiety is a major determinant of the absorption of dietary flavonoid glycosides in man. Free Radic. Res. 1999, 31, 569-573. [CrossRef]

45. Izumi, T.; Piskula, M.K.; Osawa, S.; Obata, A.; Tobe, K.; Saito, M.; Kataoka, S.; Kubota, Y.; Kikuchi, M. Soy isoflavone aglycones are absorbed faster and in higher amounts than their glucosides in humans. J. Nutr. 2000, 130, 1695-1699. [CrossRef]

46. Hostetler, G.; Riedl, K.; Cardenas, H.; Diosa-Toro, M.; Arango, D.; Schwartz, S.; Doseff, A.I. Flavone deglycosylation increases their anti-inflammatory activity and absorption. Mol. Nutr. Food Res. 2012, 56, 558-569. [CrossRef]

47. Wen, X.; Walle, T. Methylated flavonoids have greatly improved intestinal absorption and metabolic stability. Drug Metab. Dispos. 2006, 34, 1786-1792. [CrossRef]

48. Surichan, S.; Androutsopoulos, V.P.; Sifakis, S.; Koutala, E.; Tsatsakis, A.; Arroo, R.R.; Boarder, M.R. Bioactivation of the citrus flavonoid nobiletin by CYP1 enzymes in MCF7 breast adenocarcinoma cells. Food Chem. Toxicol. 2012, 50, 3320-3328. [CrossRef] 
49. Wei, G.-J.; Hwang, L.; Tsai, C.-L. Absolute bioavailability, pharmacokinetics and excretion of 5,7,3' $4^{\prime}$-tetramethoxyflavone in rats. J. Funct. Food 2014, 7, 136-141. [CrossRef]

50. Heim, K.E.; Tagliaferro, A.R.; Bobilya, D.J. Flavonoid antioxidants: Chemistry, metabolism and structure-activity relationships. J. Nutr. Biochem. 2002, 13, 572-584. [CrossRef]

51. Singh, M.; Kaur, M.; Silakari, O. Flavones: An important scaffold for medicinal chemistry. Eur. J. Med. Chem. 2014, 84, 206-239. [CrossRef]

52. Nicholas, C.; Batra, S.; Vargo, M.A.; Voss, O.H.; Gavrilin, M.A.; Wewers, M.D.; Guttridge, D.C.; Grotewold, E.; Doseff, A.I. Apigenin blocks lipopolysaccharide-induced lethality in vivo and proinflammatory cytokines expression by inactivating NF-kB through the suppression of p65 phosphorylation. J. Immunol. 2007, 179, 7121-7127. [CrossRef]

53. Lin, H.Y.; Shen, S.C.; Lin, C.W.; Yang, L.Y.; Chen, Y.C. Baicalein inhibition of hydrogen peroxide-induced apoptosis via ROS-dependent heme oxygenase 1 gene expression. Biochim. Biophys. Acta 2007, 1773, 1073-1086. [CrossRef]

54. Pérez-Cano, F.J.; Castell, M. Flavonoids, inflammation and immune system. Nutrients 2016, 8, 659. [CrossRef]

55. Peluso, I.; Miglio, C.; Morabito, G.; Ioannone, F.; Serafini, M. Flavonoids and immune function in human: A systematic review. Crit. Rev. Food Sci. Nutr. 2015, 55, 383-395. [CrossRef]

56. Damianaki, A.; Bakogeorgou, E.; Kampa, M.; Notas, G.; Hatzoglou, A.; Panagiotou, S.; Gemetzi, C.; Kouroumalis, E.; Martin, P.M.; Castanas, E. Potent inhibitory action of red wine polyphenols on human breast cancer cells. J. Cell. Biochem. 2000, 78, 429-441. [CrossRef]

57. Lin, C.H.; Chang, C.Y.; Lee, K.R.; Lin, H.J.; Chen, T.H.; Wan, L. Flavones inhibit breast cancer proliferation through the Akt/FOXO3a signaling pathway. BMC Cancer 2015, 15, 958. [CrossRef]

58. Cho, S.G.; Woo, S.M.; Ko, S.G. Butein suppresses breast cancer growth by reducing a production of intracellular reactive oxygen species. J. Exp. Clin. Cancer Res. 2014, 33, 51. [CrossRef] [PubMed]

59. Taabodi, M.; May, E.B.; Mack, K.M.; Squibb, K.S.; Ishaque, A.B. Oxidative stress pathways of flavonoid toxicity in human breast tumor cells. Int. J. Clin. Exp. Pathol. 2017, 10, 2554-2567.

60. Knickle, A.; Fernando, W.; Greenshields, A.L.; Rupasinghe, H.V.; Hoskin, D.W. Myricetin-induced apoptosis of triple-negative breast cancer cells is mediated by the iron-dependent generation of reactive oxygen species from hydrogen peroxide. Food Chem. Toxicol. 2018, 118, 154-167. [CrossRef] [PubMed]

61. Chobot, V.; Hadacek, F. Exploration of pro-oxidant and antioxidant activities of the flavonoid myricetin. Redox Rep. 2011, 16, 242-247. [CrossRef] [PubMed]

62. Procházková, D.; Boušová, I.; Wilhelmová, N. Antioxidant and prooxidant properties of flavonoids. Fitoterapia 2011, 82, 513-523. [CrossRef]

63. Zhao, X.-C.; Tian, L.; Cao, J.-G.; Liu, F. Induction of apoptosis by 5,7-dihydroxy-8-nitrochrysin in breast cancer cells: The role of reactive oxygen species and Akt. Int. J. Oncol. 2010, 37, 1345-1352.

64. Samarghandian, S.; Azimi-Nezhad, M.; Borji, A.; Hasanzadeh, M.; Jabbari, F.; Farkhondeh, T.; Samini, M. Inhibitory and cytotoxic activities of chrysin on human breast adenocarcinoma cells by induction of apoptosis. Pharmacogn. Mag. 2016, 12, S436. [PubMed]

65. Kim, T.H.; Woo, J.S.; Kim, Y.K.; Kim, K.H. Silibinin induces cell death through reactive oxygen species-dependent downregulation of notch-1/ERK/Akt signaling in human breast cancer cells. J. Pharmacol. Exp. Ther. 2014, 349, 268-278. [CrossRef]

66. Arango, D.; Parihar, A.; Villamena, F.A.; Wang, L.; Freitas, M.A.; Grotewold, E.; Doseff, A.I. Apigenin induces DNA damage through the PKC $\delta$-dependent activation of ATM and H2AX causing down-regulation of genes involved in cell cycle control and DNA repair. Biochem. Pharmacol. 2012, 84, 1571-1580. [CrossRef]

67. Martínez-Pérez, C.; Ward, C.; Turnbull, A.K.; Mullen, P.; Cook, G.; Meehan, J.; Jarman, E.J.; Thomson, P.I.; Campbell, C.J.; McPhail, D. Antitumour activity of the novel flavonoid Oncamex in preclinical breast cancer models. Br. J. Cancer 2016, 114, 905-916. [CrossRef] [PubMed]

68. Jiang, Y.-X.; Dai, Y.-Y.; Pan, Y.-F.; Wu, X.-M.; Yang, Y.; Bian, K.; Zhang, D.-D. Total flavonoids from Radix Glycyrrhiza exert anti-inflammatory and antitumorigenic effects by inactivating iNOS signaling pathways. Evid. Based Complement. Alternat. Med. 2018, 2018, 6714282. [CrossRef] [PubMed]

69. Hong, J.; Fristiohady, A.; Nguyen, C.H.; Milovanovic, D.; Huttary, N.; Krieger, S.; Hong, J.; Geleff, S.; Birner, P.; Jäger, W. Apigenin and luteolin attenuate the breaching of MDA-MB231 breast cancer spheroids through the lymph endothelial barrier in vitro. Front. Pharmacol. 2018, 9, 220. [CrossRef] [PubMed] 
70. Sica, A.; Larghi, P.; Mancino, A.; Rubino, L.; Porta, C.; Totaro, M.G.; Rimoldi, M.; Biswas, S.K.; Allavena, P.; Mantovani, A. Macrophage polarization in tumour progression. Semin. Cancer Biol. 2008, 18, 349-355. [CrossRef] [PubMed]

71. Condeelis, J.; Pollard, J.W. Macrophages: Obligate partners for tumor cell migration, invasion, and metastasis. Cell 2006, 124, 263-266. [CrossRef] [PubMed]

72. Pollard, J.W. Tumour-educated macrophages promote tumour progression and metastasis. Nat. Rev. Cancer 2004, 4, 71. [CrossRef]

73. Gabrilovich, D.I.; Nagaraj, S. Myeloid-derived suppressor cells as regulators of the immune system. Nat. Rev. Immunol. 2009, 9, 162. [CrossRef]

74. Franklin, R.A.; Liao, W.; Sarkar, A.; Kim, M.V.; Bivona, M.R.; Liu, K.; Pamer, E.G.; Li, M.O. The cellular and molecular origin of tumor-associated macrophages. Science 2014, 344, 921-925. [CrossRef]

75. Medrek, C.; Pontén, F.; Jirström, K.; Leandersson, K. The presence of tumor associated macrophages in tumor stroma as a prognostic marker for breast cancer patients. BMC Cancer 2012, 12, 306. [CrossRef]

76. De Palma, M.; Lewis, C.E. Macrophage regulation of tumor responses to anticancer therapies. Cancer Cell 2013, 23, 277-286. [CrossRef] [PubMed]

77. DeNardo, D.G.; Brennan, D.J.; Rexhepaj, E.; Ruffell, B.; Shiao, S.L.; Madden, S.F.; Gallagher, W.M.; Wadhwani, N.; Keil, S.D.; Junaid, S.A. Leukocyte complexity predicts breast cancer survival and functionally regulates response to chemotherapy. Cancer Discov. 2011, 1, 54-67. [CrossRef] [PubMed]

78. Nakasone, E.S.; Askautrud, H.A.; Kees, T.; Park, J.-H.; Plaks, V.; Ewald, A.J.; Fein, M.; Rasch, M.G.; Tan, Y.-X.; Qiu, J. Imaging tumor-stroma interactions during chemotherapy reveals contributions of the microenvironment to resistance. Cancer Cell 2012, 21, 488-503. [CrossRef] [PubMed]

79. Diaz-Montero, C.M.; Salem, M.L.; Nishimura, M.I.; Garrett-Mayer, E.; Cole, D.J.; Montero, A. Increased circulating myeloid-derived suppressor cells correlate with clinical cancer stage, metastatic tumor burden, and doxorubicin-cyclophosphamide chemotherapy. Cancer Immunol. Immunother. 2009, 58, 49-59. [CrossRef]

80. Ditsworth, D.; Zong, W.-X. NF-kappaB: Key mediator of inflammation-associated cancer. Cancer Biol. Ther. 2004, 3, 1214-1216. [CrossRef] [PubMed]

81. Karin, M.; Greten, F.R.J. NF-кB: Linking inflammation and immunity to cancer development and progression. Nat. Rev. Immunol. 2005, 5, 749-756. [CrossRef] [PubMed]

82. Blonska, M.; Czuba, Z.; Krol, W. Effect of flavone derivatives on interleukin-1 $\beta$ (IL-1 $\beta$ ) mRNA expression and IL-1 $\beta$ protein synthesis in stimulated RAW 264.7 macrophages. Scand. J. Immunol. 2003, 57, 162-166. [CrossRef] [PubMed]

83. Liang, Y.-C.; Huang, Y.-T.; Tsai, S.-H.; Lin-Shiau, S.-Y.; Chen, C.-F.; Lin, J.-K. Suppression of inducible cyclooxygenase and inducible nitric oxide synthase by apigenin and related flavonoids in mouse macrophages. Carcinogenesis 1999, 20, 1945-1952. [CrossRef]

84. Woo, H.-M.; Kang, J.-H.; Kawada, T.; Yoo, H.; Sung, M.-K.; Yu, R. Active spice-derived components can inhibit inflammatory responses of adipose tissue in obesity by suppressing inflammatory actions of macrophages and release of monocyte chemoattractant protein-1 from adipocytes. Life Sci. 2007, 80, 926-931. [CrossRef]

85. Cardenas, H.; Arango, D.; Nicholas, C.; Duarte, S.; Nuovo, G.J.; He, W.; Voss, O.H.; Gonzalez-Mejia, M.; Guttridge, D.C.; Grotewold, E. Dietary apigenin exerts immune-regulatory activity in vivo by reducing NF-kB activity, halting leukocyte infiltration and restoring normal metabolic function. Int. J. Mol. Sci. 2016, 17, 323. [CrossRef]

86. Liao, Y.; Shen, W.; Kong, G.; Lv, H.; Tao, W.; Bo, P.J.P.o. Apigenin induces the apoptosis and regulates MAPK signaling pathways in mouse macrophage ANA-1 cells. PLoS ONE 2014, 9, e92007. [CrossRef]

87. Nair, M.P.; Mahajan, S.; Reynolds, J.L.; Aalinkeel, R.; Nair, H.; Schwartz, S.A.; Kandaswami, C. The flavonoid quercetin inhibits proinflammatory cytokine (tumor necrosis factor alpha) gene expression in normal peripheral blood mononuclear cells via modulation of the NF- $\beta$ system. Clin. Vaccine Immunol. 2006, 13, 319-328. [CrossRef]

88. Zhang, X.; Wang, G.; Gurley, E.C.; Zhou, H. Flavonoid apigenin inhibits lipopolysaccharide-induced inflammatory response through multiple mechanisms in macrophages. PLoS ONE 2014, 9, e107072. [CrossRef]

89. Elyasinia, F.; Keramati, M.R.; Ahmadi, F.; Rezaei, S.; Ashouri, M.; Parsaei, R.; Yaghoubi, M.; Elyasinia, F.; Aboutorabi, A.; Kaviani, A. Neutrophil-lymphocyte ratio in different stages of breast cancer. Acta Med. Iran. 2017, 55, 228-232. 
90. Zielińska-Przyjemska, M.; Ignatowicz, E. Citrus fruit flavonoids influence on neutrophil apoptosis and oxidative metabolism. Phytother. Res. 2008, 22, 1557-1562. [CrossRef]

91. Palucka, K.; Coussens, L.M.; O'shaughnessy, J. Dendritic cells, inflammation and breast cancer. Cancer J. 2013, 19, 511-516. [CrossRef]

92. Yoneyama, S.; Kawai, K.; Tsuno, N.H.; Okaji, Y.; Asakage, M.; Tsuchiya, T.; Yamada, J.; Sunami, E.; Osada, T.; Kitayama, J.; et al. Epigallocatechin gallate affects human dendritic cell differentiation and maturation. J. Allergy Clin. Immunol. 2008, 121, 209-214. [CrossRef]

93. Harris, G.K.; Qian, Y.; Leonard, S.S.; Sbarra, D.C.; Shi, X. Luteolin and chrysin differentially inhibit cyclooxygenase-2 expression and scavenge reactive oxygen species but similarly inhibit prostaglandin-E2 formation in RAW 264.7 cells. J. Nutr. 2006, 136, 1517-1521. [CrossRef]

94. Rathee, P.; Chaudhary, H.; Rathee, S.; Rathee, D.; Kumar, V.; Kohli, K. Mechanism of action of flavonoids as anti-inflammatory agents: A review. Inflamm. Allergy Drug Targets 2009, 8, 229-235. [CrossRef]

95. Comalada, M.; Ballester, I.; Bailon, E.; Sierra, S.; Xaus, J.; Galvez, J.; de Medina, F.S.; Zarzuelo, A. Inhibition of pro-inflammatory markers in primary bone marrow-derived mouse macrophages by naturally occurring flavonoids: Analysis of the structure-activity relationship. Biochem. Pharmacol. 2006, 72, 1010-1021. [CrossRef]

96. Zhang, S.; Yang, X.; Morris, M.E. Flavonoids are inhibitors of breast cancer resistance protein (ABCG2)-mediated transport. Mol. Pharmacol. 2004, 65, 1208-1216. [CrossRef] [PubMed]

97. Sinha, S.; Amin, H.; Nayak, D.; Bhatnagar, M.; Kacker, P.; Chakraborty, S.; Kitchlu, S.; Vishwakarma, R.; Goswami, A.; Ghosal, S. Assessment of microtubule depolymerization property of flavonoids isolated from Tanacetum gracile in breast cancer cells by biochemical and molecular docking approach. Chem. Biol. Interact. 2015, 239, 1-11. [CrossRef]

98. Arango, D.; Morohashi, K.; Yilmaz, A.; Kuramochi, K.; Parihar, A.; Brahimaj, B.; Grotewold, E.; Doseff, A.I. Molecular basis for the action of a dietary flavonoid revealed by the comprehensive identification of apigenin human targets. Proc. Natl. Acad. Sci. USA 2013, 110, E2153-E2162. [CrossRef] [PubMed]

99. Zhou, Y.; Rajabi, H.; Kufe, D. Mucin 1 C-terminal subunit oncoprotein is a target for small-molecule inhibitors. Mol. Pharmacol. 2011, 79, 886-893. [CrossRef]

100. Xu, L.; Zhang, L.; Bertucci, A.M.; Pope, R.M.; Datta, S.K. Apigenin, a dietary flavonoid, sensitizes human T cells for activation-induced cell death by inhibiting PKB/Akt and NF-kB activation pathway. Immunol. Lett. 2008, 121, 74-83. [CrossRef]

101. Huang, R.-Y.; Yu, Y.-L.; Cheng, W.-C.; OuYang, C.-N.; Fu, E.; Chu, C.-L. Immunosuppressive effect of quercetin on dendritic cell activation and function. J. Immunol. 2010, 184, 6815-6821. [CrossRef]

102. Seo, H.S.; Ku, J.M.; Choi, H.S.; Woo, J.K.; Lee, B.H.; Kim, D.S.; Song, H.J.; Jang, B.H.; Shin, Y.C.; Ko, S.G. Apigenin overcomes drug resistance by blocking the signal transducer and activator of transcription 3 signaling in breast cancer cells. Oncol. Rep. 2017, 38, 715-724. [CrossRef]

103. Iriti, M.; Kubina, R.; Cochis, A.; Sorrentino, R.; Varoni, E.M.; Kabała-Dzik, A.; Azzimonti, B.; Dziedzic, A.; Rimondini, L.; Wojtyczka, R.D. Rutin, a quercetin glycoside, restores chemosensitivity in human breast cancer cells. Mini-Rev. Med. Chem. 2017, 31, 1529-1538. [CrossRef]

104. Chisholm, K.; Bray, B.J.; Rosengren, R.J. Tamoxifen and epigallocatechin gallate are synergistically cytotoxic to MDA-MB-231 human breast cancer cells. Anticancer Drugs 2004, 15, 889-897. [CrossRef] [PubMed]

105. Rai, G.; Mishra, S.; Suman, S.; Shukla, Y. Resveratrol improves the anticancer effects of doxorubicin in vitro and in vivo models: A mechanistic insight. Phytomedicine 2016, 23, 233-242. [CrossRef] [PubMed]

106. Liu, R.; Ji, P.; Liu, B.; Qiao, H.; Wang, X.; Zhou, L.; Deng, T.; Ba, Y. Apigenin enhances the cisplatin cytotoxic effect through p53-modulated apoptosis. Oncol. Lett. 2017, 13, 1024-1030. [CrossRef]

107. Wu, K.; Wang, C.; D'Amico, M.; Lee, R.J.; Albanese, C.; Pestell, R.G.; Mani, S. Flavopiridol and trastuzumab synergistically inhibit proliferation of breast cancer cells: Association with selective cooperative inhibition of cyclin D1-dependent kinase and Akt signaling pathways. Mol. Cancer Ther. 2002, 1, 695-706.

108. Nagaria, T.S.; Williams, J.L.; Leduc, C.; Squire, J.A.; Greer, P.A.; Sangrar, W. Flavopiridol synergizes with sorafenib to induce cytotoxicity and potentiate antitumorigenic activity in EGFR/HER-2 and mutant RAS/RAF breast cancer model systems. Neoplasia 2013, 15, 939-951. [CrossRef]

109. Cao, X.; Liu, B.; Cao, W.; Zhang, W.; Zhang, F.; Zhao, H.; Meng, R.; Zhang, L.; Niu, R.; Hao, X.; et al. Autophagy inhibition enhances apigenin-induced apoptosis in human breast cancer cells. Chin. J. Cancer Res. 2013, 25, 212-222. [CrossRef] 
110. Ding, J.; Polier, G.; Kohler, R.; Giaisi, M.; Krammer, P.H.; Li-Weber, M. Wogonin and related natural flavones overcome tumor necrosis factor-related apoptosis-inducing ligand (TRAIL) protein resistance of tumors by down-regulation of c-FLIP protein and up-regulation of TRAIL receptor 2 expression. J. Biol. Chem. 2012, 287, 641-649. [CrossRef]

111. Ando, C.; Takahashi, N.; Hirai, S.; Nishimura, K.; Lin, S.; Uemura, T.; Goto, T.; Yu, R.; Nakagami, J.; Murakami, S. Luteolin, a food-derived flavonoid, suppresses adipocyte-dependent activation of macrophages by inhibiting JNK activation. FEBS Lett. 2009, 583, 3649-3654. [CrossRef]

112. Zhang, L.; Han, Y.-J.; Zhang, X.; Wang, X.; Bao, B.; Qu, W.; Liu, J. Luteolin reduces obesity-associated insulin resistance in mice by activating AMPK $\alpha 1$ signalling in adipose tissue macrophages. Diabetologia 2016, 59, 2219-2228. [CrossRef]

113. Dong, J.; Zhang, X.; Zhang, L.; Bian, H.-X.; Xu, N.; Bao, B.; Liu, J. Quercetin reduces obesity-associated adipose tissue macrophage infiltration and inflammation in mice: A mechanism including AMPK $\alpha 1 / S I R T 1$. J. Lipid Res. 2014, 55, 363-374. [CrossRef]

114. Du, G.; Lin, H.; Yang, Y.; Zhang, S.; Wu, X.; Wang, M.; Ji, L.; Lu, L.; Yu, L.; Han, G. Dietary quercetin combining intratumoral doxorubicin injection synergistically induces rejection of established breast cancer in mice. Int. Immunopharmacol. 2010, 10, 819-826. [CrossRef]

115. Mafuvadze, B.; Liang, Y.; Besch-Williford, C.; Zhang, X.; Hyder, S.M. Apigenin induces apoptosis and blocks growth of medroxyprogesterone acetate-dependent BT-474 xenograft tumors. Horm. Cancer 2012, 3, 160-171. [CrossRef]

116. Chen, D.; Landis-Piwowar, K.R.; Chen, M.S.; Dou, Q.P. Inhibition of proteasome activity by the dietary flavonoid apigenin is associated with growth inhibition in cultured breast cancer cells and xenografts. Breast Cancer Res. 2007, 9, R80. [CrossRef] [PubMed]

117. Ke, J.Y.; Banh, T.; Hsiao, Y.H.; Cole, R.M.; Straka, S.R.; Yee, L.D.; Belury, M.A.J. Citrus flavonoid naringenin reduces mammary tumor cell viability, adipose mass, and adipose inflammation in obese ovariectomized mice. Mol. Nutr. Food. Res. 2017, 61, 1600934. [CrossRef] [PubMed]

118. Yang, X.; Wang, Q.; Pang, Z.-R.; Pan, M.-R.; Zhang, W. Flavonoid-enriched extract from Hippophae rhamnoides seed reduces high fat diet induced obesity, hypertriglyceridemia, and hepatic triglyceride accumulation in C57BL/6 mice. Pharm. Biol. 2017, 55, 1207-1214. [CrossRef]

119. Rossi, E.L.; Khatib, S.A.; Doerstling, S.S.; Bowers, L.W.; Pruski, M.; Ford, N.A.; Glickman, R.D.; Niu, M.; Yang, P.; Cui, Z. Resveratrol inhibits obesity-associated adipose tissue dysfunction and tumor growth in a mouse model of postmenopausal claudin-low breast cancer. Mol. Carcinog. 2018, 57, 393-407. [CrossRef]

120. Huang, Z.; Fang, F.; Wang, J.; Wong, C.-W.J. Structural activity relationship of flavonoids with estrogen-related receptor gamma. FEBS Lett. 2010, 584, 22-26. [CrossRef]

121. Pick, A.; Müller, H.; Mayer, R.; Haenisch, B.; Pajeva, I.K.; Weigt, M.; Bönisch, H.; Müller, C.E.; Wiese, M. Structure-activity relationships of flavonoids as inhibitors of breast cancer resistance protein (BCRP). Bioorg. Med. Chem. 2011, 19, 2090-2102. [CrossRef] [PubMed]

122. Imai, Y.; Tsukahara, S.; Asada, S.; Sugimoto, Y. Phytoestrogens/flavonoids reverse breast cancer resistance protein/ABCG2-mediated multidrug resistance. Bioorg. Med. Chem. 2004, 64, 4346-4352. [CrossRef] [PubMed]

123. Katayama, K.; Masuyama, K.; Yoshioka, S.; Hasegawa, H.; Mitsuhashi, J.; Sugimoto, Y. Flavonoids inhibit breast cancer resistance protein-mediated drug resistance: Transporter specificity and structure-activity relationship. Cancer Chemother. Pharmacol. 2007, 60, 789-797. [CrossRef]

124. Juvale, K.; Stefan, K.; Wiese, M.J. Synthesis and biological evaluation of flavones and benzoflavones as inhibitors of BCRP/ABCG2. Eur. J. Med. Chem. 2013, 67, 115-126. [CrossRef] [PubMed]

125. Zhang, J.; Zhang, L.; Xu, Y.; Jiang, S.; Shao, Y. Deciphering the binding behavior of flavonoids to the cyclin dependent kinase 6/cyclin D complex. PLOS ONE 2018, 13, e0196651. [CrossRef] [PubMed]

126. Yin, F.; Giuliano, A.E.; Law, R.E.; Van, A.H. Apigenin inhibits growth and induces G2/M arrest by modulating cyclin-CDK regulators and ERK MAP kinase activation in breast carcinoma cells. Anticancer Res. 2001, 21, 413-420. [PubMed]

127. Hermenean, A.; Ardelean, A. Targeting the cytoskeleton with plant-bioactive compounds in cancer therapy. In Cytoskeleton-Structure, Dynamics, Function and Disease; IntechOpen: London, UK, 2017.

128. Xuan, Y.; Wang, J.; Ban, L.; Lu, J.-J.; Yi, C.; Li, Z.; Yu, W.; Li, M.; Xu, T.; Yang, W. hnRNPA2/B1 activates cyclooxygenase-2 and promotes tumor growth in human lung cancers. Mol. Oncol. 2016, 10, 610-624. [CrossRef] [PubMed] 
129. Venables, J.P.; Klinck, R.; Koh, C.; Gervais-Bird, J.; Bramard, A.; Inkel, L.; Durand, M.; Couture, S.; Froehlich, U.; Lapointe, E.; et al. Cancer-associated regulation of alternative splicing. Nat. Struct. Mol. Biol. 2009, 16, 670-676. [CrossRef] [PubMed]

130. Guha, M.; Srinivasan, S.; Guja, K.; Mejia, E.; Garcia-Diaz, M.; Johnson, F.B.; Ruthel, G.; Kaufman, B.A.; Rappaport, E.F.; Glineburg, M.R. HnRNPA2 is a novel histone acetyltransferase that mediates mitochondrial stress-induced nuclear gene expression. Cell Discov. 2016, 2, 16045. [CrossRef]

131. Han, N.; Li, W.; Zhang, M.J. The function of the RNA-binding protein hnRNP in cancer metastasis. J. Cancer Res. Ther. 2013, 9, 129-134.

132. Aslan, E.; Guler, C.; Adem, S.J. In vitro effects of some flavonoids and phenolic acids on human pyruvate kinase isoenzyme M2. J. Enzyme Inhib. Med. Chem. 2016, 31, 314-317. [CrossRef]

133. David, C.J.; Chen, M.; Assanah, M.; Canoll, P.; Manley, J.L. HnRNP proteins controlled by c-Myc deregulate pyruvate kinase mRNA splicing in cancer. Nature 2010, 463, 364-368. [CrossRef]

134. Lin, Y.; Lv, F.; Liu, F.; Guo, X.; Fan, Y.; Gu, F.; Gu, J.; Fu, L.J. High expression of pyruvate kinase M2 is associated with chemosensitivity to epirubicin and 5-fluorouracil in breast cancer. J. Cancer 2015, 6, 1130. [CrossRef]

135. Chiavarina, B.; Whitaker-Menezes, D.; Martinez-Outschoorn, U.E.; Witkiewicz, A.K.; Birbe, R.; Howell, A.; Pestell, R.G.; Smith, J.; Daniel, R.; Sotgia, F.; et al. Pyruvate kinase expression (PKM1 and PKM2) in cancer-associated fibroblasts drives stromal nutrient production and tumor growth. Cancer Biol. Ther. 2011, 12, 1101-1113. [CrossRef]

136. Wong, N.; De Melo, J.; Tang, D. PKM2, a central point of regulation in cancer metabolism. Int. J. Cell Biol. 2013, 2013. [CrossRef]

137. Goode, G.; Gunda, V.; Chaika, N.V.; Purohit, V.; Yu, F.; Singh, P.K. MUC1 facilitates metabolomic reprogramming in triple-negative breast cancer. PLoS ONE 2017, 12, e0176820.

138. Li, J.; Inoue, J.; Choi, J.-M.; Nakamura, S.; Yan, Z.; Fushinobu, S.; Kamada, H.; Kato, H.; Hashidume, T.; Shimizu, M.J. Identification of the flavonoid luteolin as a repressor of the transcription factor hepatocyte nuclear factor $4 \alpha$. J. Biol. Chem. 2015, 290, 24021-24035. [CrossRef]

139. Bosetti, C.; Spertini, L.; Parpinel, M.; Gnagnarella, P.; Lagiou, P.; Negri, E.; Franceschi, S.; Montella, M.; Peterson, J.; Dwyer, J.; et al. Flavonoids and breast cancer risk in Italy. Cancer Epidemiol. Biomarkers Prev. 2005, 14, 805-808. [CrossRef] [PubMed]

140. Fink, B.N.; Steck, S.E.; Wolff, M.S.; Britton, J.A.; Kabat, G.C.; Schroeder, J.C.; Teitelbaum, S.L.; Neugut, A.I.; Gammon, M.D. Dietary flavonoid intake and breast cancer risk among women on long island. Am. J. Epidemiol. 2007, 165, 514-523. [CrossRef]

141. Hui, C.; Qi, X.; Qianyong, Z.; Xiaoli, P.; Jundong, Z.; Mantian, M. Flavonoids, flavonoid subclasses and breast cancer risk: A meta-analysis of epidemiologic studies. PLoS ONE 2013, 8, e54318. [CrossRef] [PubMed]

142. Peeters, P.; Keinan-Boker, L.; Van Der Schouw, Y.; Grobbee, D. Phytoestrogens and breast cancer risk. Breast Cancer Res. Treat. 2003, 77, 171-183. [CrossRef] [PubMed]

143. Peterson, J.; Lagiou, P.; Samoli, E.; Lagiou, A.; Katsouyanni, K.; La Vecchia, C.; Dwyer, J.; Trichopoulos, D. Flavonoid intake and breast cancer risk: A case-control study in Greece. Br. J. Cancer 2003, 89, 1255-1259. [CrossRef]

144. Parihar, A.; Grotewold, E.; Doseff, A.I. Flavonoid dietetics: Mechanisms and emerging roles of plant nutraceuticals. In Pigments in Fruits and Vegetables; Springer: New York, NY, USA, 2015; pp. 93-126.

145. Hanahan, D.; Weinberg, R.A. Hallmarks of cancer: The next generation. Cell 2011, 144, 646-674. [CrossRef]

146. Choi, J.-A.; Kim, J.-Y.; Lee, J.-Y.; Kang, C.-M.; Kwon, H.-J.; Yoo, Y.-D.; Kim, T.-W.; Lee, Y.-S.; Lee, S.-J. Induction of cell cycle arrest and apoptosis in human breast cancer cells by quercetin. Int. J. Oncol. 2001, 19, 837-844. [CrossRef]

147. Madunić, I.V.; Madunić, J.; Antunović, M.; Paradžik, M.; Garaj-Vrhovac, V.; Breljak, D.; Marijanović, I.; Gajski, G. Apigenin, a dietary flavonoid, induces apoptosis, DNA damage, and oxidative stress in human breast cancer MCF-7 and MDA MB-231 cells. Naunyn-Schmiedeberg's Arch. Pharmacol. 2018, 391, 537-550. [CrossRef]

148. Nguyen, L.T.; Lee, Y.-H.; Sharma, A.R.; Park, J.-B.; Jagga, S.; Sharma, G.; Lee, S.-S.; Nam, J.-S. Quercetin induces apoptosis and cell cycle arrest in triple-negative breast cancer cells through modulation of Foxo3a activity. Korean J. Physiol. Pharmacol. 2017, 21, 205-213. [CrossRef] 
149. Sun, D.-W.; Zhang, H.-D.; Mao, L.; Mao, C.-F.; Chen, W.; Cui, M.; Ma, R.; Cao, H.-X.; Jing, C.-W.; Wang, Z.; et al. Luteolin inhibits breast cancer development and progression in vitro and in vivo by suppressing notch signaling and regulating MiRNAs. Cell Physiol. Biochem. 2015, 37, 1693-1711. [CrossRef]

150. Zhang, H.-W.; Hu, J.-J.; Fu, R.-Q.; Liu, X.; Zhang, Y.-H.; Li, J.; Liu, L.; Li, Y.-N.; Deng, Q.; Luo, Q.-S.; et al. Flavonoids inhibit cell proliferation and induce apoptosis and autophagy through downregulation of PI3K $\gamma$ mediated PI3K/AKT/mTOR/p70S6K/ULK signaling pathway in human breast cancer cells. Sci. Rep. 2018, 8, 11255. [CrossRef]

151. Balkwill, F.R.; Capasso, M.; Hagemann, T. The tumor microenvironment at a glance. J. Cell Sci. 2012, 125, 5591-5596. [CrossRef] [PubMed]

152. Hanahan, D.; Coussens, L.M. Accessories to the crime: Functions of cells recruited to the tumor microenvironment. Cancer Cell 2012, 21, 309-322. [CrossRef]

153. Mbeunkui, F.; Johann, D.J. Cancer and the tumor microenvironment: A review of an essential relationship. Cancer Chemother. Pharmacol. 2009, 63, 571-582. [CrossRef]

154. Wang, G.; Wang, J.-J.; Guan, R.; Du, L.; Gao, J.; Fu, X.-L.J. Strategies to target glucose metabolism in tumor microenvironment on cancer by flavonoids. Nutr. Cancer 2017, 69, 534-554. [CrossRef] [PubMed]

155. Tan, J.; Buache, E.; Chenard, M.-P.; Dali-Youcef, N.; Rio, M.-C. Adipocyte is a non-trivial, dynamic partner of breast cancer cells. Int. J. Dev. Biol. 2011, 55, 851-859. [CrossRef]

156. Hoy, A.J.; Balaban, S.; Saunders, D.N. Adipocyte-tumor cell metabolic crosstalk in breast cancer. Trends Mol. Med. 2017, 23, 381-392. [CrossRef]

157. Nickel, A.; Blücher, C.; Al Kadri, O.; Schwagarus, N.; Müller, S.; Schaab, M.; Thiery, J.; Burkhardt, R.; Stadler, S.C. Adipocytes induce distinct gene expression profiles in mammary tumor cells and enhance inflammatory signaling in invasive breast cancer cells. Sci. Rep. 2018, 8, 9482. [CrossRef]

158. Bougaret, L.; Delort, L.; Billard, H.; Le Huede, C.; Boby, C.; De la Foye, A.; Rossary, A.; Mojallal, A.; Damour, O.; Auxenfans, C. Adipocyte/breast cancer cell crosstalk in obesity interferes with the anti-proliferative efficacy of tamoxifen. PLoS ONE 2018, 13, e0191571. [CrossRef] [PubMed]

159. Hsu, C.-L.; Yen, G.-C. Effects of flavonoids and phenolic acids on the inhibition of adipogenesis in 3T3-L1 adipocytes. J. Agric. Food Chem. 2007, 55, 8404-8410. [CrossRef] [PubMed]

160. Harmon, A.W.; Harp, J.B. Differential effects of flavonoids on 3T3-L1 adipogenesis and lipolysis. Am. J. Physiol. Cell Physiol. 2001, 280, C807-C813. [CrossRef] [PubMed]

161. Corrêa, L.H.; Corrêa, R.; Farinasso, C.M.; de Sant'Ana Dourado, L.P.; Magalhães, K.G. Adipocytes and macrophages interplay in the orchestration of tumor microenvironment: New implications in cancer progression. Front. Immunol. 2017, 8, 1129. [CrossRef] [PubMed]

162. Qian, B.-Z.; Li, J.; Zhang, H.; Kitamura, T.; Zhang, J.; Campion, L.R.; Kaiser, E.A.; Snyder, L.A.; Pollard, J.W. CCL2 recruits inflammatory monocytes to facilitate breast-tumour metastasis. Nature 2011, 475, 222-225. [CrossRef] [PubMed]

163. Bauer, D.; Redmon, N.; Mazzio, E.; Soliman, K.F. Apigenin inhibits TNF $\alpha / \mathrm{IL}-1 \alpha$-induced CCL2 release through IKBK-epsilon signaling in MDA-MB-231 human breast cancer cells. PLoS ONE 2017, 12, e0175558. [CrossRef]

164. Zheng, X.; Turkowski, K.; Mora, J.; Brüne, B.; Seeger, W.; Weigert, A.; Savai, R. Redirecting tumor-associated macrophages to become tumoricidal effectors as a novel strategy for cancer. Oncotarget 2017, 8, 48436-48452. [CrossRef]

165. Genard, G.; Lucas, S.; Michiels, C. Reprogramming of tumor-associated macrophages with anticancer therapy therapies: Radiotherapy versus chemo-and immunotherapies. Front. Immunol. 2017, 8, 828. [CrossRef]

166. De Oliveira Júnior, R.G.; Ferraz, C.A.A.; da Silva Almeida, J.R.G.; Grougnet, R.; Thiéry, V.; Picot, L. Sensitization of tumor cells to chemotherapy by natural products: A systematic review of preclinical data and molecular mechanisms. Fitoterapia 2018, 129, 383-400. [CrossRef]

167. Guestini, F.; McNamara, K.M.; Ishida, T.; Sasano, H. Triple negative breast cancer chemosensitivity and chemoresistance: Current advances in biomarkers indentification. Expert Opin. Ther. Targets 2016, 20, 705-720. [CrossRef]

168. Di Pietro, A.; Conseil, G.; Perez-Victoria, J.; Dayan, G.; Baubichon-Cortay, H.; Trompier, D.; Steinfels, E.; Jault, J.-M.; De Wet, H.; Maitrejean, M.; et al. Modulation by flavonoids of cell multidrug resistance mediated by P-glycoprotein and related ABC transporters. Cell. Mol. Life Sci. 2002, 59, 307-322. [CrossRef] [PubMed] 
169. Hansen, R.K.; Parra, I.; Lemieux, P.; Oesterreich, S.; Hilsenbeck, S.G.; Fuqua, S.A. Hsp27 overexpression inhibits doxorubicin-induced apoptosis in human breast cancer cells. Breast Cancer Res. Treat. 1999, 56, 185-194. [CrossRef]

170. Díaz-Chávez, J.; Fonseca-Sánchez, M.A.; Arechaga-Ocampo, E.; Flores-Pérez, A.; Palacios-Rodríguez, Y.; Domínguez-Gómez, G.; Marchat, L.A.; Fuentes-Mera, L.; Mendoza-Hernández, G.; Gariglio, P. Proteomic profiling reveals that resveratrol inhibits HSP27 expression and sensitizes breast cancer cells to doxorubicin therapy. PLoS ONE 2013, 8, e64378. [CrossRef] [PubMed]

171. Voss, O.H.; Batra, S.; Kolattukudy, S.J.; Gonzalez-Mejia, M.E.; Smith, J.B.; Doseff, A.I. Binding of caspase-3 prodomain to heat shock protein 27 regulates monocyte apoptosis by inhibiting caspase-3 proteolytic activation. J. Biol. Chem. 2007, 282, 25088-25099. [CrossRef]

172. Li, X.; Wang, J.-N.; Huang, J.-M.; Xiong, X.-K.; Chen, M.-F.; Ong, C.-N.; Shen, H.-M.; Yang, X.-F. Chrysin promotes tumor necrosis factor (TNF)-related apoptosis-inducing ligand (TRAIL) induced apoptosis in human cancer cell lines. Oncogene 2004, 23, 7712. [CrossRef]

173. Shi, R.-X.; Ong, C.-N.; Shen, H.-M. Luteolin sensitizes tumor necrosis factor- $\alpha$-induced apoptosis in human tumor cells. Oncogene 2004, 23, 7712. [CrossRef]

174. Horinaka, M.; Yoshida, T.; Shiraishi, T.; Nakata, S.; Wakada, M.; Sakai, T. The dietary flavonoid apigenin sensitizes malignant tumor cells to tumor necrosis factor-related apoptosis-inducing ligand. Mol. Cancer Ther. 2006, 5, 945-951. [CrossRef] [PubMed]

175. Peterson, G.; Barnes, S. Genistein inhibition of the growth of human breast cancer cells: Independence from estrogen receptors and the multi-drug resistance gene. Biochem. Biophys. Res. Commun. 1991, 179, 661-667. [CrossRef]

176. Zhang, Y.; Song, T.T.; Cunnick, J.E.; Murphy, P.A.; Hendrich, S. Daidzein and genistein glucuronides in vitro are weakly estrogenic and activate human natural killer cells at nutritionally relevant concentrations. J. Nutr. 1999, 129, 399-405. [CrossRef]

177. Fenga, C.; Costa, C.; Caruso, E.; Raffa, L.; Alibrando, C.; Gangemi, S.; Docea, A.O.; Tsatsakis, A.M. Current evidence on the protective effect of dietary polyphenols on breast cancer. Farmacia 2016, 64, 1-12.

178. Toledo, E.; Salas-Salvadó, J.; Donat-Vargas, C.; Buil-Cosiales, P.; Estruch, R.; Ros, E.; Corella, D.; Fitó, M.; $\mathrm{Hu}$, F.B.; Arós, F.; et al. Mediterranean diet and invasive breast cancer risk among women at high cardiovascular risk in the PREDIMED trial: A randomized clinical trial. JAMA Intern. Med. 2015, 175, 1752-1760. [CrossRef]

179. Turati, F.; Carioli, G.; Bravi, F.; Ferraroni, M.; Serraino, D.; Montella, M.; Giacosa, A.; Toffolutti, F.; Negri, E.; Levi, F.; et al. Mediterranean diet and breast cancer risk. J. Nutr. 1999, 129, 399-405. [CrossRef]

180. Chen, M.; Rao, Y.; Zheng, Y.; Wei, S.; Li, Y.; Guo, T.; Yin, P. Association between soy isoflavone intake and breast cancer risk for pre-and post-menopausal women: A meta-analysis of epidemiological studies. PLOS ONE 2014, 9, e89288. [CrossRef]

181. Yamamoto, S.; Sobue, T.; Kobayashi, M.; Sasaki, S.; Tsugane, S. Soy, isoflavones, and breast cancer risk in Japan. J. Natl. Cancer Inst. 2003, 95, 906-913. [CrossRef]

182. Trock, B.J.; Hilakivi-Clarke, L.; Clarke, R. Meta-analysis of soy intake and breast cancer risk. J. Natl. Cancer Inst. 2006, 98, 459-471. [CrossRef]

183. Cho, W. Cancer Chemoprevention and Treatment by Diet Therapy; Springer: New York, NY, USA, 2013.

184. Caballero, B. The global epidemic of obesity: An overview. Epidemiol Rev. 2007, 29, 1-5. [CrossRef]

185. Mitchell, N.S.; Catenacci, V.A.; Wyatt, H.R.; Hill, J.O. Obesity: Overview of an epidemic. Psychiatr. Clin. North Am. 2011, 34, 717-732. [CrossRef]

186. Picon-Ruiz, M.; Morata-Tarifa, C.; Valle-Goffin, J.J.; Friedman, E.R.; Slingerland, J.M. Obesity and adverse breast cancer risk and outcome: Mechanistic insights and strategies for intervention. CA Cancer J. Clin. 2017, 67, 378-397. [CrossRef]

187. Cecchini, R.S.; Costantino, J.P.; Cauley, J.A.; Cronin, W.M.; Wickerham, D.L.; Land, S.R.; Weissfeld, J.L.; Wolmark, N. Body mass index and the risk for developing invasive breast cancer among high-risk women in NSABP P-1 and STAR breast cancer prevention trials. Cancer Prev. Res. (Phila.) 2012, 5, 583-592. [CrossRef]

188. Neuhouser, M.L.; Aragaki, A.K.; Prentice, R.L.; Manson, J.E.; Chlebowski, R.; Carty, C.L.; Ochs-Balcom, H.M.; Thomson, C.A.; Caan, B.J.; Tinker, L.F. Overweight, obesity, and postmenopausal invasive breast cancer risk: A secondary analysis of the women's health initiative randomized clinical trials. JAMA Oncol. 2015, 1, 611-621. [CrossRef] [PubMed] 
189. Reeves, G.K.; Pirie, K.; Beral, V.; Green, J.; Spencer, E.; Bull, D. Cancer incidence and mortality in relation to body mass index in the Million Women Study: Cohort study. BMJ 2007, 335, 1134. [CrossRef] [PubMed]

190. Gaudet, M.M.; Press, M.F.; Haile, R.W.; Lynch, C.F.; Glaser, S.L.; Schildkraut, J.; Gammon, M.D.; Thompson, W.D.; Bernstein, J.L. Risk factors by molecular subtypes of breast cancer across a population-based study of women 56 years or younger. Breast Cancer Res. Treat. 2011, 130, 587-597. [CrossRef]

191. Pierobon, M.; Frankenfeld, C.L. Obesity as a risk factor for triple-negative breast cancers: A systematic review and meta-analysis. Breast Cancer Res. Treat. 2013, 137, 307-314. [CrossRef]

192. Yang, X.R.; Chang-Claude, J.; Goode, E.L.; Couch, F.J.; Nevanlinna, H.; Milne, R.L.; Gaudet, M.; Schmidt, M.K.; Broeks, A.; Cox, A. Associations of breast cancer risk factors with tumor subtypes: A pooled analysis from the Breast Cancer Association Consortium studies. J. Natl. Cancer Inst. 2010, 103, 250-263. [CrossRef]

193. Dirat, B.; Bochet, L.; Dabek, M.; Daviaud, D.; Dauvillier, S.; Majed, B.; Wang, Y.Y.; Meulle, A.; Salles, B.; Le Gonidec, S. Cancer-associated adipocytes exhibit an activated phenotype and contribute to breast cancer invasion. Cancer Res. 2011, 71, 2455-2465. [CrossRef] [PubMed]

194. De Heredia, F.P.; Gómez-Martínez, S.; Marcos, A. Obesity, inflammation and the immune system. Proc. Nutr. Soc. 2012, 71, 332-338. [CrossRef]

195. Chang, S.; Buzdar, A.U.; Hursting, S.D. Inflammatory breast cancer and body mass index. J. Clin. Oncol. 1998, 16, 3731-3735. [CrossRef]

196. Iyengar, N.M.; Hudis, C.A.; Dannenberg, A.J. Obesity and inflammation: New insights into breast cancer development and progression. Am. Soc. Clin. Oncol. Educ. Book. 2013, 33, 46-51. [CrossRef]

197. Vaysse, C.; Lømo, J.; Garred, Ø.; Fjeldheim, F.; Lofteroed, T.; Schlichting, E.; McTiernan, A.; Frydenberg, H.; Husøy, A.; Lundgren, S. Inflammation of mammary adipose tissue occurs in overweight and obese patients exhibiting early-stage breast cancer. NPJ Breast Cancer 2017, 3, 19. [CrossRef]

198. Sun, X.; Casbas-Hernandez, P.; Bigelow, C.; Makowski, L.; Jerry, D.J.; Schneider, S.S.; Troester, M.A. Normal breast tissue of obese women is enriched for macrophage markers and macrophage-associated gene expression. Breast Cancer Res. Treat. 2012, 131, 1003-1012. [CrossRef]

199. Osman, M.A.; Hennessy, B.T. Obesity correlation with metastases development and response to first-line metastatic chemotherapy in breast cancer. Clin. Med. Insights Oncol. 2015, 9, 105-112. [CrossRef] [PubMed]

200. Poudel, B.; Nepali, S.; Xin, M.; Ki, H.H.; Kim, Y.H.; Kim, D.K.; Lee, Y.M. Flavonoids from Triticum aestivum inhibit adipogenesis in 3T3-L1 cells by upregulating the insig pathway. Mol. Med. Rep. 2015, 12, 3139-3145. [CrossRef] [PubMed]

201. Cowen, S.; McLaughlin, S.; Hobbs, G.; Coad, J.; Martin, K.; Olfert, I.; Vona-Davis, L. High-fat, high-calorie diet enhances mammary carcinogenesis and local inflammation in MMTV-PyMT mouse model of breast cancer. Cancers 2015, 7, 1125-1142. [CrossRef]

202. Cranford, T.L.; Velázquez, K.T.; Enos, R.T.; Sougiannis, A.T.; Bader, J.E.; Carson, M.S.; Bellone, R.R.; Chatzistamou, I.; Nagarkatti, M.; Murphy, E.A.; et al. Effects of high fat diet-induced obesity on mammary tumorigenesis in the PyMT/MMTV murine model. Cancer Biol. Ther. 2019, 20, 487-496. [CrossRef]

203. Wang, Y.; Gapstur, S.M.; Gaudet, M.M.; Peterson, J.J.; Dwyer, J.T.; McCullough, M.L. Evidence for an association of dietary flavonoid intake with breast cancer risk by estrogen receptor status is limited-3. J. Nutr. 2014, 144, 1603-1611. [CrossRef] [PubMed]

204. Nechuta, S.J.; Caan, B.J.; Chen, W.Y.; Lu, W.; Chen, Z.; Kwan, M.L.; Flatt, S.W.; Zheng, Y.; Zheng, W.; Pierce, J.P. Soy food intake after diagnosis of breast cancer and survival: An in-depth analysis of combined evidence from cohort studies of US and Chinese women. Am. J. Clin. Nutr. 2012, 96, 123-132. [CrossRef]

205. Cho, Y.; Kim, J.; Park, K.; Lim, S.; Shin, A.; Sung, M.; Ro, J. Effect of dietary soy intake on breast cancer risk according to menopause and hormone receptor status. Eur. J. Clin. Nutr. 2010, 64, 924. [CrossRef]

206. Vitolins, M.Z.; Milliron, B.-J.; Hopkins, J.O.; Fulmer, A.; Lawrence, J.; Melin, S.; Case, D. Weight loss intervention in survivors of ER/PR-negative breast cancer. Clin. Med. Insights Women's Health 2014, 7, 17-24. [CrossRef] [PubMed]

207. Khan, S.A.; Chatterton, R.T.; Michel, N.; Bryk, M.; Lee, O.; Ivancic, D.; Heinz, R.; Zalles, C.M.; Helenowski, I.B.; Jovanovic, B.D. Soy isoflavone supplementation for breast cancer risk reduction: A randomized phase II trial. Cancer Prev. Res. 2012, 5, 309-319. [CrossRef]

208. El-Rayes, B.F.; Gadgeel, S.; Parchment, R.; Lorusso, P.; Philip, P.A. A phase I study of flavopiridol and docetaxel. Investig. New Drugs 2006, 24, 305. [CrossRef] 
209. Maskarinec, G.; Suzuki, S.; Pagano, I.S.; Morimoto, Y.; Franke, A.A.; Ehya, H. Cytology in nipple aspirate fluid during a randomized soy food intervention among premenopausal women. Nutr. Cancer 2013, 65, 1116-1121. [CrossRef]

210. Pop, E.A.; Fischer, L.M.; Coan, A.D.; Gitzinger, M.; Nakamura, J.; Zeisel, S.H. Effects of a high daily dose of soy isoflavones on DNA damage, apoptosis and estrogenic outcomes in healthy, postmenopausal women-A Phase I clinical trial. Menopause 2008, 15, 684. [CrossRef]

211. Gemcitabine Hydrochloride and Genistein in Treating Women with Stage IV Breast Cancer. Available online: https://clinicaltrials.gov/ct2/show/NCT00244933?term=genistein\&cond=breast+cancer\&rank=1 (accessed on 24 January 2019).

212. Docetaxel and Flavopiridol in Treating Patients with Locally Advanced or Metastatic Breast Cancer. Available online: https://clinicaltrials.gov/ct2/show/NCT00020332?term=flavopiridol\&cond=cancer\&rank=4 (accessed on 24 January 2019).

213. Wu, A.; Koh, W.; Wang, R.; Lee, H.; Yu, M. Soy intake and breast cancer risk in Singapore Chinese Health Study. Br. J. Cancer 2008, 99, 196. [CrossRef]

214. Wang, L.; Lee, I.M.; Zhang, S.M.; Blumberg, J.B.; Buring, J.E.; Sesso, H.D. Dietary intake of selected flavonols, flavones, and flavonoid-rich foods and risk of cancer in middle-aged and older women. Am. J. Clin. Nutr. 2009, 89, 905-912. [CrossRef] [PubMed]

215. Wada, K.; Nakamura, K.; Tamai, Y.; Tsuji, M.; Kawachi, T.; Hori, A.; Takeyama, N.; Tanabashi, S.; Matsushita, S.; Tokimitsu, N. Soy isoflavone intake and breast cancer risk in Japan: From the Takayama study. Int. J. Cancer 2013, 133, 952-960. [CrossRef] [PubMed]

216. Torres-Sanchez, L.; Galvan-Portillo, M.; Wolff, M.S.; Lopez-Carrillo, L. Dietary consumption of phytochemicals and breast cancer risk in Mexican women. Public Health Nutr. 2009, 12, 825-831. [CrossRef] [PubMed]

217. Thanos, J.; Cotterchio, M.; Boucher, B.A.; Kreiger, N.; Thompson, L.U. Adolescent dietary phytoestrogen intake and breast cancer risk (Canada). Cancer Causes Control 2006, 17, 1253-1261. [CrossRef] [PubMed]

218. Zamora-Ros, R.; Ferrari, P.; González, C.A.; Tjønneland, A.; Olsen, A.; Bredsdorff, L.; Overvad, K.; Touillaud, M.; Perquier, F.; Fagherazzi, G.; et al. Dietary flavonoid and lignan intake and breast cancer risk according to menopause and hormone receptor status in the European Prospective Investigation into Cancer and Nutrition (EPIC) Study. Breast Cancer Res. Treat. 2013, 139, 163-176. [CrossRef]

219. Dos Santos Silva, I.; Mangtani, P.; McCormack, V.; Bhakta, D.; McMichael, A.J.; Sevak, L. Phyto-oestrogen intake and breast cancer risk in South Asian women in England: Findings from a population-based case-control study. Cancer Causes Control 2004, 15, 805-818. [CrossRef]

220. Iwasaki, M.; Hamada, G.S.; Nishimoto, I.N.; Netto, M.M.; Motola, J.; Laginha, F.M.; Kasuga, Y.; Yokoyama, S.; Onuma, H.; Nishimura, H.; et al. Dietary isoflavone intake and breast cancer risk in case-control studies in Japanese, Japanese Brazilians, and non-Japanese Brazilians. Breast Cancer Res. Treat. 2009, 116, 401-411. [CrossRef] [PubMed]

221. Zhang, C.; Ho, S.C.; Lin, F.; Cheng, S.; Fu, J.; Chen, Y. Soy product and isoflavone intake and breast cancer risk defined by hormone receptor status. Cancer Sci. 2010, 101, 501-507. [CrossRef]

222. Pantavos, A.; Ruiter, R.; Feskens, E.F.; de Keyser, C.E.; Hofman, A.; Stricker, B.H.; Franco, O.H.; Kiefte-de Jong, J.C. Total dietary antioxidant capacity, individual antioxidant intake and breast cancer risk: The R otterdam study. Int. J. Cancer 2015, 136, 2178-2186. [CrossRef] [PubMed]

223. Morimoto, Y.; Maskarinec, G.; Park, S.-Y.; Ettienne, R.; Matsuno, R.K.; Long, C.; Steffen, A.D.; Henderson, B.E.; Kolonel, L.N.; Le Marchand, L. Dietary isoflavone intake is not statistically significantly associated with breast cancer risk in the Multiethnic Cohort. Br. J. Nutr. 2014, 112, 976-983. [CrossRef]

224. Crew, K.D.; Brown, P.; Greenlee, H.; Bevers, T.B.; Arun, B.K.; Hudis, C.A.; McArthur, H.L.; Chang, J.; Rimawi, M.F.; Vornik, L.; et al. Phase IB randomized, double-blinded, placebo-controlled, dose escalation study of polyphenon $\mathrm{E}$ in women with hormone receptor-negative breast cancer. Cancer Prev. Res. 2012, 5 , 1144-1154. [CrossRef]

225. Dostal, A.M.; Samavat, H.; Bedell, S.; Torkelson, C.; Wang, R.; Swenson, K.; Le, C.; Wu, A.H.; Ursin, G.; Yuan, J.-M.J.F.; et al. The safety of green tea extract supplementation in postmenopausal women at risk for breast cancer: Results of the Minnesota Green Tea Trial. Food Chem. Toxicol. 2015, 83, 26-35. [CrossRef] 
226. A Clinical Trial Comparing Gemcitabine and Carboplatin with and without P276-00 in Subjects with Metastatic Triple Negative Breast Cancer, with a Run-in of Escalating Dose of P276-00 Added to Gemcitabine and Carboplatin. Available online: https:/clinicaltrials.gov/ct2/show/NCT01333137?term=flavone\&cond= cancer\&rank=1 (accessed on 24 January 2019).

227. Effects of Soy Compounds on Breast Cancer, Prostate Cancer, and Bone Health. Available online: https://clinicaltrials.gov/ct2/show/NCT00200824?term=isoflavone\&cond=cancer\&rank=10 (accessed on 24 January 2019).

228. Wu, A.H.; Spicer, D.; Garcia, A.; Tseng, C.-C.; Hovanessian-Larsen, L.; Sheth, P.; Martin, S.E.; Hawes, D.; MacDonald, H.; Tripathy, D. Double-blind randomized 12-month soy intervention had no effects on breast MRI fibroglandular tissue density or mammographic density. Cancer Prev. Res. 2015, 8, 942-951. [CrossRef]

229. Sak, K. Cytotoxicity of dietary flavonoids on different human cancer types. Pharmacogn. Rev. 2014, 8, 122. [CrossRef] [PubMed]

230. Murota, K.; Nakamura, Y.; Uehara, M. Flavonoid metabolism: The interaction of metabolites and gut microbiota. Biosci. Biotechnol. Biochem. 2018, 82, 600-610. [CrossRef] [PubMed]

231. Thilakarathna, S.H.; Rupasinghe, H.P. Flavonoid bioavailability and attempts for bioavailability enhancement. Nutrients 2013, 5, 3367-3387. [CrossRef]

232. Vitaglione, P.; Donnarumma, G.; Napolitano, A.; Galvano, F.; Gallo, A.; Scalfi, L.; Fogliano, V. Protocatechuic acid is the major human metabolite of cyanidin-glucosides. J. Nutr. 2007, 137, 2043-2048. [CrossRef] [PubMed]

233. Kawabata, K.; Yoshioka, Y.; Terao, J. Role of Intestinal Microbiota in the Bioavailability and Physiological Functions of Dietary Polyphenols. Molecules 2019, 24, 370. [CrossRef] [PubMed]

234. Dwivedi, S.; Shukla, S.; Goel, A.; Sharma, P.; Khattri, S.; Kumar Pant, K. Nutrigenomics in Breast Cancer; Springer: New York, NY, USA, 2014. [CrossRef]

235. Steiner, C.; Arnould, S.; Scalbert, A.; Manach, C. Isoflavones and the prevention of breast and prostate cancer: New perspectives opened by nutrigenomics. Br. J. Nutr. 2008, 99, ES78-ES108. [CrossRef] [PubMed]

236. Egert, S.; Rimbach, G. Which sources of flavonoids: Complex diets or dietary supplements? Adv. Nutr. 2011, 2, 8-14. [CrossRef] [PubMed] 